\title{
Selecting (In) and Crowding Out: \\ Experimental Evidence of the Power of \\ Religious Authority in Afghanistan ${ }^{*}$
}

\author{
Luke N. Condra \\ Mohammad Isaqzadeh ${ }^{\dagger}$ \\ Sera Linardi
}

This version: July 24, 2015

\begin{abstract}
We unpack the psychological influence of a Muslim cleric's power over the poor in an experiment in Afghanistan. The same cleric requests contributions for a hospital from daylaborers when dressed as a civilian and as a cleric. In Civilian condition, 50\% contribute and 17\% make large contributions; in Cleric condition, $83 \%$ contribute but large contributions fall. Through counterfactual simulations, we find that the clerical garb compels unmotivated subjects to contribute (selection), but causes those who initially were generous to reduce their contribution (crowding out). The backlash is present only among those with formal education but is counteracted when the cleric adds a recitation of Qur'anic verses. Overall, this suggests that education mediates whether people automatically associate religious authorities with the omnipresent.
\end{abstract}

\footnotetext{
"For their helpful suggestions and feedback we thank Rikhil Bhavnani, Ed Condra, Jim Fearon, Bethany Lacina, Paul Nelson, Jake Shapiro, and participants at ASREC, SEA, ISA, WPSA, MPSA, and the Harris School of Public Policy's Political Economy Workshop. Erin Carbone and Jikuo Lu provided excellent research assistance. We gratefully acknowledge the Hewlett International Grant Program, the Global Studies Center, and the Central Research Development Fund, all of the University of Pittsburgh, for financial support. This research was approved by the University of Pittsburgh's Institutional Review Board (PRO14050038).

- Graduate School of Public and International Affairs, University of Pittsburgh, lcondra@pitt.edu. † Department of Political Science and Public Administration, American University of Afghanistan, mohammad.isaqzadeh@gmail.com.

‡ Graduate School of Public and International Affairs, University of Pittsburgh, linardi@pitt.edu.
} 
The importance of religious actors in large-scale social and political mobilization in the Islamic world has been steadily increasing for many years. Middle East experts have argued that Muslim clerics are enormously influential in motivating local collective action'. They are the cornerstone of the fundraising efforts of Islamic organizations such as Hezbollah and the Mahdi Army in Iraq, both for their social service provision efforts as well as their militant arms. $^{2}$ They are also very effective in recruiting perpetrators of violence ${ }^{3}-$ particularly the poor and uneducated ${ }^{4}$ - so much so that radical clerics have been among the targets of U.S drone strikes. ${ }^{5}$ Examples of Muslim clerics' influence appear across weak states. For example, the Nigerian government's polio vaccination campaign became extremely successful only when it involved Muslim clerics in its public education outreach. ${ }^{6}$

\section{' Patel 2007.}

${ }^{2}$ Berman 2009, 133-34. "Even if you cannot participate yourselves alongside us in the Jihad, your [financial] donation to us from the money that Allah gave you is not less important [than participating in the Jihad].” Hamas communiqué from November 2002, quoted in Levitt 2006, 66.

${ }^{3}$ Fathi 1981, Al-Kadhimi 2013.

${ }^{4}$ Bueno de Mesquita 2005.

${ }^{5}$ Becker and Shane 2012, Ernst 2015, Johnston and Sarbahi 2015.

${ }^{6}$ Hogan 2014, Nasir, et al. 2014. A researcher in the vaccination campaign's pilot program said, “The missing link with campaigns in the past was that we didn't figure out how to connect with the society...From now on, we will maximize the use of traditional and religious leaders as part of the campaign"” (Hogan 2014). 
In influencing behavior, clerics could be "just like elites in other socially visible professions"; that is, they may be effective mobilizers just because especially charismatic and persuasive individuals select into the profession. However, personal characteristics aside, an individual may be imbued with unique psychological influence on their audience by virtue of being a cleric. To understand a cleric's power to mobilize broadly, it is critical to isolate this psychological channel since the social mechanisms that govern the role of a cleric as a cue-giver within his own congregation (i.e., self-selection and social network dynamics $)^{8}$ are much less present when a cleric directs his appeal outside his congregation. And because "the most subtle dynamics, such as how relative status is signaled and established, depend on the resources made available by face to face interaction and a shared physical setting, ${ }^{, 9}$ it is important that the existence of this positionally-induced influence is investigated in a shared physical setting. ${ }^{10}$

We present the first experiment to do just this. ${ }^{11}$ In our experiment, a Muslim cleric in Kabul, Afghanistan appears in person to solicit contributions for a public good (a

\section{${ }^{7}$ Olson 2009, 375 .}

${ }^{8}$ See Guth, et al. 1997, Olson 2000, Djupe and Gilbert 2003, Smidt 2004.

${ }^{9}$ Nohria and Eccles 1992.

${ }^{10}$ Moving away from face-to-face interaction to electronic or text-mediated interaction has been known to flatten inequalities in hierarchy (Dubrovsky, et al. 1991).

"There have been some studies that manipulate the identity of the deliverer of a message to be from a religious authority in writing, through video, or in the form of a picture (Djupe and Gwiasda 2010, McCauley 2014, Chhibber and Sekhon 2015). The first two studies (written and video) found no effect of religious authority, while the last one did. 
hospital) from low income day laborers under two experimental conditions: while dressed as a civilian (Civilian) and while dressed as a cleric (Cleric). By having an actual cleric interact face-to-face with the subjects, we isolate the additional impact of positional authority after preserving the multidimensional characteristics (speech, gesture, etc.) of an individual that would self-select into this high-status position. Indeed, the cleric's distinction is apparent even in his civilian clothing: $80 \%$ of subjects who guessed his profession stated professions of authority, the most common one being doctor or government official.

We attempt to unpack the psychological influence of the cleric's authority, since "[w]hile our intuition is that religious elites influence the political behavior of their audiences, just how that influence takes place is essentially unknown". ${ }^{2}$ We focus on two mechanisms. First, clergy could wield influence by virtue of their position as just one of many human authority figures, ${ }^{13}$ focusing behavior on the salient norm, which in this case would be the Islamic norm of sadaqah, giving "what one can” to charity. Second, because "[a cleric's] 'industry' is, in an important sense, not of this world", ${ }^{14}$ an individual may be seen as having a special affiliation with the omnipresent, which would observe and punish bad behavior and reward good behavior. While human authority motivates compliance through control and social pressure - with its attendant backlash ${ }^{15}$ - association with the omnipresent results in a much more powerful type of behavioral change, one consistent

\footnotetext{
${ }^{12}$ Djupe and Calfano 2009, 1.

${ }^{13}$ Milgram 1974.

${ }^{14}$ Olson 2009, 375.

${ }^{15}$ Holmstrom and Milgrom 1991, Frey 1993, Falk and Kosfeld 2006.
} 
with a genuine increase in intrinsic motivation. ${ }^{16}$

We find that contributions to a hospital are $66 \%$ more likely when the solicitor is dressed in his clerical garments (83\%) compared to when he is dressed as a civilian (50\%). However, this increase in contribution incidence does not correspond to an increase in average contribution. By simulating counterfactuals, we find that this lack of increase can be explained by two opposing reactions to the cleric: selection (in) and crowding out. Those who are predicted to give nothing in the Civilian condition are contributing the minimum in the Cleric condition, but those who were generous in the Civilian condition are now also giving the minimum in the Cleric condition, particularly if they are formally educated. These reactions are not consistent with an increase in generosity from being reminded of higher ideals, or from seeking rewards from an omnipresent God. Instead, they suggest an imposition of human authority to conform to a norm and the resulting crowding out of intrinsic motivation.

However, this does not paint a complete picture of the cleric's power. While civilians do not wield verbatim quotations of scripture as a motivating and legitimating tool in this setting, clerics do. Moreover, previous research has found that the negative effect from the imposition of control can be counteracted through justification. ${ }^{17}$ We therefore add a third treatment, the Cleric + Scripture treatment, which proceeds identically to the Cleric treatment, but adds a quote from the Qur'an at the end of the solicitation script

\footnotetext{
${ }^{16}$ Shariff and Norenzayan 2007.

${ }^{17}$ Schnedler and Vadovic 2011, Silverman, et al. 2014.
} 
reminding subjects that God rewards and looks approvingly on giving. ${ }^{18}$ Consistent with this psychological literature, the use of this rhetorical tool appears to counteract the backlash to the cleric's exercise of power. The contribution of educated high contributors is restored to what it was in the Civilian condition while the contribution of all the other groups increases further, resulting in average contributions that are twice that of the Civilian and Cleric conditions.

This paper makes several contributions to our understanding of how religious authority mobilizes the faithful toward collective action. First, we show that when presented face-to-face, a Muslim cleric's identity alone can have considerable effects on people’s willingness to contribute to a public good, a behavior that is extremely meaningful for politics in developing countries. ${ }^{19}$ This is an important finding in light of other studies that cast doubt on clergy's ability to have such an effect on behavior. ${ }^{20}$ Second, we identify and

${ }^{18}$ Clerics in Afghanistan are trained to recite and read scripture in a specific cadence and accent. Therefore, not only is it contextually unnatural for subjects to hear verbatim quotation of scripture by a non-cleric, but the cleric would have to attempt to dispense with his customary way of reciting scripture were he to recite it as a 'civilian' so as not to give away the fact that he is an educated cleric. We therefore do not pursue a test of Civilian+Scripture.

${ }^{19}$ Fearon, et al. 2009, Grossman and Baldassarri 2012.

${ }^{20}$ The conditions under which clergy can influence opinion is far from settled as an empirical matter. This is true both in Islam (e.g., Jamal, et al. 2014, McCauley 2014), and in the American case, where the literature reveals inconsistent effects within a congregation (cf. Fetzer 2001, Djupe and Gilbert 2009, Djupe and Hunt 2009). 
adjudicate between competing mechanisms through which the cleric's power could operate (supernatural vs. human authority), showing that - at least in this context - the Muslim cleric's influence comes from his position as a human authority by virtue of the crowding out effect. Third, we identify the mediating influence of formal education on one's readiness to follow religious authority. This result may provide some context to the Taliban's opposition to formal education and the number of schools that they have closed in Afghanistan since 2001. ${ }^{21}$ Fourth, we also show how resistance from the educated to religious authority can be counteracted through the cleric's use of scriptural quotes. Fifth, we do all of this in a setting that addresses concerns about external validity in experiments. We situate the experiment in Afghanistan, a weak state; we recruit from the low-income population about which we wish to make inferences; we use an actual religious authority, rather than a hypothetical one or religious symbols; and we measure his ability on a policyrelevant task: fundraising for public services.

The rest of the paper is organized as follows. In Section 2, we review the literature on how clergy influences behavior and explain our particular approach in our study. We then review experiments linking either religious priming or the presence of an authority to effect changes in behavior, which inform our hypotheses and experimental design. In the third section, we summarize our lab-in-the-field experiment. Section 4 presents our data and the empirical results of our analysis. Section 5 discusses and interprets those results in the context of competing explanations for how religious authority affects behavior. A concluding section reviews our arguments and summarizes our contributions.

${ }^{21}$ Human Rights Watch 2006. 


\section{Literature Review}

Research in political psychology has generally shown that people interpret messages differently depending on the identity of the deliverer and the framing of the message; ${ }^{22}$ recent survey experiments suggest more specifically that manipulation of religious associations increases acceptance of political messages. Evangelical Protestants indicated more agreement with controversial political statements attributed to a religious authority of the same affiliation. ${ }^{23}$ Calfano and Paolino show that white evangelicals are more likely to support black political candidates who use religious code phrases, ${ }^{24}$ and Chhibber and Sekhon show that Indian Muslims exhibit greater confidence in political appeals from individuals who are photographed in a Muslim cap than from those who do not. ${ }^{25}$

However, these studies do not shed adequate light on how religious authorities influence behavior. First, subjects in these studies do not actually interact with the religious authority; instead they are exposed only to the experimenter's written description of a person. This is important because identity features can be revealed through subtle cues of body language and appearance, which can be strategically manipulated; ${ }^{26}$ we want to capture - and control for - the real possibility that charismatic, persuasive individuals may select into the clerical profession and separate that from influence wielded through the position's association with the supernatural. Moreover, people may respond differently to face-to-face

\footnotetext{
${ }_{22}^{22}$ Asch 1952, Kuklinski and Hurley 1996, Druckman 2001.

${ }^{23}$ Djupe and Gwiasda 2010, Robinson 2010.

${ }^{24}$ Calfano and Paolino 2010.

${ }^{25}$ Chhibber and Sekhon 2015.

${ }^{26}$ Patel 2012.
} 
interaction with authority compared to less personal and artificial interaction. Second, it is unclear how to use these statements of support to measure willingness to engage in costly actions. Finally, and more importantly, these and other studies in this vein have not sufficiently adjudicated between competing mechanisms.

Observational studies show a positive association between religion and prosocial behavior, such as activism, volunteering, or contributing to public goods. ${ }^{27}$ However, it is difficult to draw inferences about how religion affects behavior from observational studies of naturally occurring religious identity, as associations between religiosity and prosocial behavior can be either correlational or causal (i.e., people are religious because they have these prosocial tendencies or vice versa). Experimental studies, in which a random sample of subjects is exposed to stimuli that activate associations with religion, get around this problem. ${ }^{28}$

But within the experimental literature on religion and politics, there is a debate on whether religious influence should be conceptualized as primarily psychological or social in origin. ${ }^{29}$ The answer probably depends, in part, on the distinction Guth et al. make between cue-giving and direct action: that is, whether the cleric's target audience is inside or outside his own congregation. ${ }^{30}$ Inside one's congregation, the dominant forces are self-selection

\footnotetext{
${ }^{27}$ See review in Bekkers and Wiepking 2011.

${ }^{28}$ These studies include subliminal (Johnson, et al. 2010), implicit (Benjamin, et al. 2010), explicit (Carpenter and Marshall 2009), or contextual primes (Sagioglou and Forstmann 2013). See review in Shariff, et al. forthcoming.

${ }^{29}$ Djupe and Gilbert 2009, 107.

${ }^{30}$ Guth, et al. 1997.
} 
into the congregation and the particular social dynamics of that context, which drive how opinions are formed. ${ }^{31}$ Psychological forces on individuals may matter much more in the context of direct action.

We build our theoretical framework from mechanisms suggested by psychology and economics experiments where religiously primed subjects face monetary (costly) decisions. Subjects appear to cheat less in games and hence earn less when recalling the Ten Commandments; ${ }^{32}$ they are also more willing to bear monetary risks for others when exposed to Qur'anic quotes. ${ }^{33}$ More importantly, religiously primed subjects increase giving in the extensive and intensive margins in dictator games: non-givers are halved while very generous splits are doubled (>50:50). ${ }^{34}$ Only the religious appear to be affected, suggesting that these responses are indeed driven by the activation of pre-existing religious beliefs rather than activation of universal moral norms. These priming treatments also do not appear to affect empathy or altruism for others, ${ }^{35}$ but the resulting behavioral changes are similar to those produced by stimuli that unconsciously activate cognitive representations of being watched, even where the 'watcher' is clearly artificial and unable to monitor

\footnotetext{
${ }^{31}$ See Guth, et al. 1997, Olson 2000, Djupe and Gilbert 2003, Smidt 2004.

${ }^{32}$ Mazar, et al. 2008.

${ }^{33}$ Linardi, et al. 2015.

${ }^{34}$ Benjamin, et al. 2010 and McClendon and Riedl 2014 are exceptions: their subjects did not appear more prosocial after exposure to religious cues.

${ }^{35}$ Shariff and Norenzayan 2007, Gervais and Norenzayan 2012.
} 
behavior ${ }^{36}$ Religious priming is therefore hypothesized to activate the idea of a supernatural omnipresent watcher (such as God). ${ }^{37}$

The power of religious leaders, however, can also come from their role as an authority figure. In the course of socialization, humans develop standards that serve as guides for behavior in their many social roles. ${ }^{38}$ Authority works by making certain roles more salient and hence activates an implicit threat of self or social sanction for deviations from the norms of that role. However, this intervention may backfire. A substantial literature on "motivational crowding out" shows that agents may reduce their effort when principals impose controls such as monitoring, effort minimums, or fines. ${ }^{39}$ Interestingly, the negative effect may be counteracted if the exercise of control is justified. ${ }^{40}$

The aforementioned studies and the clear directive in Islam regarding charitable giving allow us to make predictions on the power of Muslim clerics in encouraging public goods contributions. Numerous verses from the Qur'an describe sadaqah, a private and voluntary act of giving motivated by charity and sincerity of faith. ${ }^{41}$ However, unlike zakat, which is an obligatory public act that serves as an income tax with a fixed percentage, a believer can offer sadaqah in whatever amount that one wishes, regardless of income or the

\footnotetext{
${ }^{36}$ Haley and Fessler 2005, Bateson, et al. 2006, Burnham and Hare 2007.

${ }^{37}$ Shariff and Norenzayan 2007.

${ }^{38}$ Bandura 1986.

${ }^{39}$ Frey 1993, Falk and Kosfeld 2006.

${ }^{40}$ Schnedler and Vadovic 2011, Silverman, et al. 2014.

${ }^{41}$ Al Qardawi 1999.
} 
basis of wealth. ${ }^{42}$ If religious positional authority cues the supernatural, we should see contributions increase in both the intensive and extensive margins when the solicitor is perceived to be a cleric instead of a civilian. Having the cleric quote the Qur'an should have little additional effect beyond possibly pushing contributions further along the same direction. However, if the presence of the cleric is an imposition of human authority, behavior will concentrate around the norm of sadaqah, which was made salient by his position. If individuals grudgingly comply with the cleric to fulfill their role as Muslims, more subjects will contribute; however, contributions will be minimal. Here, the marginal impact of scripture may be large.

Finally, scholars have shown that the role of religion and its effects on political behavior is mediated by income and educational attainment across a variety of contexts. The less educated are drawn disproportionately to religious sects (as opposed to churches). ${ }^{43}$ Poorer and less educated women "are more likely to take on fundamentalist and traditionalist belief systems that enhance their value as potential marriage partners." Ethan Bueno de Mesquita argues that the poorer and less educated probably are more likely to join terrorist groups, though groups' strategic selection strategies from available

\footnotetext{
${ }^{42}$ Lambarraa and Riener 2012.

${ }^{43}$ Iannaccone 1988.

${ }^{44}$ Blaydes and Linzer 2008, 577.
} 
recruits for tasks masks this fact. ${ }^{45}$ All of this would suggest that religious authority has a disparate impact across these divisions of socioeconomic status, which we investigate. ${ }^{46}$

\section{Experimental Design}

Afghanistan provides an ideal setting to pursue our research questions. Like many developing and post-conflict countries, civilian institutions in Afghanistan suffer from a deficit of legitimacy ${ }^{47}$ and public goods provision historically has been ceded to communities due to state weakness. ${ }^{48}$ Religious authority has filled the role of the state:

\footnotetext{
${ }^{45}$ Bueno de Mesquita 2005.

${ }^{46}$ It would be natural to examine how an individual's religiosity mediates the treatment effects, but this is not informative for Afghanistan, where there is low variance reported along common dimensions of religiosity. As one scholar explains, "being faithful is selfevident and natural within the Muslim population. This can be considered to hold true almost universally and represents an aspect shared by the great majority of Muslims” (ElMenouar 2014, 56). This is particularly true in Afghanistan, where $92 \%$ of respondents to a recent Pew Research Center survey reported that God is "very important" in their lives; 91\% reported praying multiple times each day; and 97\% of men reported attending mosque for salah and Jumah prayer (Bell 2012).

${ }^{47}$ Rennie 2008 .

${ }^{48}$ Beath, et al. 2013, 542 .
} 
citizens generally expect them to lend their presence and opinion on even secular issues, ${ }^{49}$ and clerics have become very influential in the social and political life of Afghan citizens. ${ }^{50}$

We conducted our field experiment in Kabul, Afghanistan, in June 2014. Our interventions were chosen with an eye toward maximizing connections to "their real-world modalities. ${ }^{911}$ The cleric, who served as the solicitor for the public good for the entire experiment, leads a mosque in Kabul and teaches students Sharia law in an Islamic seminary. As such, the baseline influence of a charismatic, educated community leader over our less-educated subjects is held constant across all our treatments. The recipient of the contributions is the Helmand Province branch of EMERGENCY (Hospital), an NGO that is widely known and well-regarded across Afghanistan for its high quality care and commitment to treat anyone..$^{52}$

Studying monetary contributions allows us to tie our experiment most closely to existing empirical results. In our experiment, the act of giving up even a small amount of money is a considerable self-sacrifice. Our subjects, Afghan day workers, are men without steady jobs who congregate at public markets and wait there to be solicited for employment opportunities for the day. When hired, employers would transport these men to various work sites, paying them about $500 \mathrm{AFN}(\$ 8.60)$ for a full day of employment. However,

\footnotetext{
${ }^{49}$ In a 2011 Asia Foundation Survey, 70\% of respondents said that religious leaders should be consulted when local problems are addressed (Tariq, et al. 2011).

${ }^{50}$ Barfield 2010, 40.

${ }^{51}$ Paluck and Green 2009, 349.

${ }^{52}$ Mogelson 2012.
} 
jobs are scarce and day workers often go a few days without being hired. Giving up any of their day's earning is therefore extremely costly for them.

Each morning, our Afghan field personnel drove several buses to one or more of the public markets in the city to recruit subjects. We chose different market locations each morning to avoid duplicate recruitment and to maximize the geographic breadth of our sample. ${ }^{53}$ Field personnel approached potential subjects in the markets to participate in a survey about the labor force in Kabul for 500 AFN. Subjects who provided oral consent were transported to the enumeration location where they waited in the courtyard once they arrived.

Based on national statistics and our own knowledge, we had good reason to assume that many of the subjects were illiterate and could not complete the survey alone. As such, we paired each subject with an enumerator. At the beginning of every session, five to seven enumerators retrieved their subjects from the courtyard and brought them to the room where the experiment took place. ${ }^{51}$ After each pair was seated behind a privacy partition, the enumerator verbally asked the survey questions and recorded the subject's responses.

\footnotetext{
${ }^{53}$ We also took pains not to recruit near the cleric's mosque so that subjects would be unlikely to know him. Subjects with whom we spoke after the experiment did not know or recognize the cleric.

${ }^{54}$ Our subject pool reflects the diversity in Kabul: most of our subjects (69\%) indicated Dari as their native language and were enumerated in Dari, the official language of Afghanistan, while $31 \%$ indicated Pashto as their native language and were enumerated in Pashto. To maintain ethnic composition across sessions, we ensure that each group of 5-7 subjects always included 1 to 2 Pashto speakers.
} 
When all subjects in the room had completed the survey, the enumerators told them the survey was completed and then handed them their payment in an envelope (six 50 AFN bills, five $20 \mathrm{AFN}$ bills, and ten $10 \mathrm{AFN}$ bills). A solicitor (the cleric) then requested contributions to the hospital under one of three experimental conditions (described below). The solicitor and all enumerators then left the room to allow subjects to make their decisions in private. Any contribution was to be left in the original envelope and dropped into a box as subjects exited the room. ${ }^{55}$ Subjects then exited the enumeration location.

In all treatments, the solicitor delivered the neutral script below; ${ }^{56}$

Thank you for completing this survey. To thank you for your participation, we would like to compensate you with 500 AFN for your time. On the table in front of you there is an envelope with 500 AFN inside. Today you also have the opportunity to donate part of your compensation to EMERGENCY in Helmand Province, in the south. As you know, EMERGENCY is committed to caring for the victims of war. The organization provides treatment to our Pashtun brothers and sisters who are victims of war in the south. We invite you to contribute to the treatment of victims of war in the region. If you would like to donate to EMERGENCY, please leave the money you wish to donate in the envelope. Remove the money you wish to keep for yourself from the envelope. If you decide not to make any donations, you can leave the envelope empty. Before you leave the room, please drop the envelope in the box by the door.

\footnotetext{
${ }^{55}$ Envelopes were unobtrusively numbered so contributions could be matched with the survey.

${ }^{56}$ The script was written in consultation with local Afghanis so that it would sound natural when delivered by both civilian and religious authorities. Since Dari is used for official communication, the solicitor read the script in Dari and his words were privately translated to Pashto by the Pashto enumerators, as necessary. Note that the cleric is Pashtun, but due to his neutral dress and demeanor and complete fluency in both languages, even our enumerators were unsure as to his ethnic identity.
} 
We conducted three treatments. In the Civilian treatment, he wore typical Afghan civilian clothes. In the Cleric treatment, he read the same script while dressed in his normal clerical garments, which constitutes only the addition of a dark turban and a dark prayer scarf over his civilian clothing. In the Cleric+Scripture treatment, the solicitor wore his clerical garments and read the same script with the addition of a verbatim quote from the Qur'an at the end: “Those who spend [for/in] Allah's cause, in prosperity and adversity, who repress their anger, and who pardon men; verily, Allah loves good-doers.”-Surah 3 (Al-Emran), verse 134.

Our analysis proceeds as follows. Our experiment involves monetary contributions to social causes and so shares many similarities with the dictator game. We allow for results from this literature to guide our approach to the analysis of the data..$^{57}$ Engel's meta-study of dictator games finds that $64 \%$ of dictators give non-zero amounts and "the willingness to give anything is indeed not driven by the same forces as the choice of the size of the contribution. ${ }^{98}$ Thus, we separately investigate the willingness to contribute (the extensive margin) and the amount contributed (the intensive margin) in the descriptive statistics (Tables 2) and in regression analysis (Tables 3 and 5). We then delve more deeply into the mechanisms behind treatment effects by simulating what each individual would have given in the baseline (Civilian) condition and comparing it with what the individual actually contributed in the two Cleric conditions (Tables 4 and 6). In terms of the treatment, we will

\footnotetext{
${ }^{57}$ The average dictator split is $30 \%$; however, this percentage is lower with higher stakes and dictators that earn the "pie" (the money to be split) (Engel 2011). Note, however, that college students are over-represented in these studies.

${ }^{58}$ Engel 2011.
} 
first analyze the effect of positional religious authority by comparing the Civilian condition to the Cleric condition. Lastly, we bring in Cleric + Scripture to investigate if the cleric's use of scriptural quotes overcomes the limitations of positional religious authority.

\section{Data and Empirical Results}

Our subject pool consisted of 305 Muslim male day laborers. The average age was 30 years old; 72\% of them were married (Table 1). The sample reflects the ethno-linguistic diversity in Afghanistan: 69\% identify with one of the ethnic minority groups (Tajiks, Hazaras, Uzbeks), while $31 \%$ identify ethnically as Pashtuns. About half of the day laborers (53\%) had no formal education at all. Those who did spent an average of eight years in school: $129(42 \%)$ had formal education with a science-based curriculum, while $15(5 \%)$ went to Qur'anic schools where the education centers on religious texts. ${ }^{59}$ Subjects have been working as day laborers for about nine years, on average. They are often unable to find work: they reported that they have only been employed for 2.6 days in the previous week and the majority of subjects $(72 \%)$ reported feeling poor. ${ }^{60}$ The average income is 3961 AFN a month (about \$69), equivalent to eight full days of employment in a month.

We ran 51 experimental sessions with 5 to 7 individuals per session: 16 Civilian sessions, 19 Cleric sessions, and 16 Cleric + Scripture sessions. To learn about how subjects

\footnotetext{
${ }^{59}$ Those who were in Qur'anic school had an average of 4 years of education.

${ }^{60}$ Rees 2009 and Delamontagne 2010 argue that the cross-national correlation between religious devotion and poverty can be better explained by relative subjective poverty. We therefore asked: "How wealthy is your household compared to other households in your neighborhood?" Subjects choose between: Poor / Below Average / Above Average / Rich.
} 
perceive the solicitor, we verbally surveyed a random sample of subjects as they were leaving their session. About $35 \%$ of subjects across all treatments decline to guess the solicitor's profession. Among those who ventured a guess in the Civilian condition, $80 \%$ of the guesses concern high status professions with doctor as the most frequent guess, followed by government official. In the Cleric and $\mathrm{Cleric}^{+}$Scripture condition, all guesses were of cleric. ${ }^{61}$

How does voluntary contribution to a public good change when the solicitor is perceived as a religious authority, as opposed to a civilian authority? The histogram in Figure 1 provides an initial snapshot. In the Civilian condition (black bar), half of the subjects contribute nothing, $12 \%$ of subjects gave the minimal amount (10 AFN), $22 \%$ gave $20 \mathrm{AFN}$ and $17 \%$ gave more than $20 \mathrm{AFN}$. The proportion of non-contributors drops to $17 \%$ in the Cleric treatment (dark gray bar). However, the mode shifts dramatically to 10 AFN (53\%), leaving the mass at $20 \mathrm{AFN}$ unchanged but decreasing amounts above $20 \mathrm{AFN}$ $(7 \%)^{62}$

Table 2 presents the summary statistics. The dramatic increase in the extensive margin as we go from Civilian to Cleric is statistically significant $(\mathrm{p}<0.01)$ and in line with

\footnotetext{
${ }^{61}$ Since subjects were surveyed verbally (due to low literacy rates) as they are leaving the location, we cannot link their guesses to their behavior in the experiment.

${ }^{62}$ Recall the denominations are in multiples of 10 , and hence $10 \mathrm{AFN}$ is the minimal amount. Five subjects (out of 305) contributed their own cash- these amounts are rounded to the nearest multiples of 10 in the figure.
} 
behavior in dictator games with religious priming. ${ }^{63}$ However, the drop in the intensive margin (from 26.63 AFN to 16.13 AFN, $\mathrm{p}<0.01$ ) is not consistent with either religious priming or unconscious activation of the omnipresent, which has not previously been shown to decrease the intensity of prosocial behavior. ${ }^{64}$ On the whole, moving from Civilian to Cleric does not increase average contributions (13.45 $\mathrm{AFN}$ to $13.39 \mathrm{AFN}, \mathrm{p}=0.98) .^{65}$ Table 3 (Panel A) confirms these summary statistics using OLS models with extensive controls and robust standard errors clustered at the session level. ${ }^{66}$

We now investigate if religious authority disproportionately affects the poor and uneducated. For this purpose, we constructed a dummy variable More Income, which takes on the value 1 if the individual earns at least the median income (4000 AFN) and zero otherwise. For education, we use the variable Formal Education from Table 1 that

${ }^{63}$ For example, an increase from $60 \%$ to $84 \%$ in Shariff and Norenzayan 2007. It is also in line with increased intensive margin from the eye-stimuli (e.g., an increase from $50 \%$ to 79\% in Haley and Fessler 2005).

${ }^{64}$ For example, the amount given conditional on contributing rose from $\$ 4.30$ (no priming) to $\$ 5.50$ (religious priming) in Shariff and Norenzayan 2007, and rose from $\$ 2.38$ (no eyespots) to $\$ 3.14$ (eyespots) in Haley and Fessler 2005 . The amount is given out of a $\$ 10$ endowment.

${ }^{65}$ The coefficient on Cleric suggests that while the likelihood of contributions rose by about $41 \%$, the size of contributions fell by $9.88 \mathrm{AFN}$ - a 37\% drop from $26.63 \mathrm{AFN}$, resulting in a statistically insignificant increase in the conditional amount contributed (2.43 AFN).

${ }^{66}$ Models include all demographic variables from Table 1, session ethnic mix, enumerator fixed effects and subjects' waiting time. See Appendix Table 1. 
takes on the value 1 if the individual had formal education (i.e., a science-based curriculum) and zero if he does not (this includes those educated in Qur'anic school). ${ }^{67} \mathrm{We}$ replaced Monthly Income and Years of Education with these dummy variables and also included their interaction with Cleric. None of the interaction terms is significant; however, the linear combinations of the coefficients suggest some interesting sources of heterogeneity.

In Panel B of Table 3, we see that Cleric has the same effect on conditional contributions across income levels (-9.70 AFN and $-9.43 \mathrm{AFN}){ }^{68}$ On the other hand, splitting across educational experience reveals that the negative effect of the cleric is only significant for those with formal education (-14.14 AFN, $\mathrm{p}<0.05$, Panel C) and not for those without formal education (-6.66 AFN, p>0.10). Though we would caution against overinterpreting this result since all our subjects are poor, the results suggest that for this subject pool, formal education appears to be a more important determinant of one's reaction to religious authority than income. ${ }^{69}$

\footnotetext{
${ }^{67}$ Results reported below on education are unaffected if we change the value of Formal Education from zero to missing for subjects who attended Qur'anic school.

${ }^{68}$ The effect on Less Income is the estimated coefficient on Cleric. The effect on More Income is the linear combination of (Cleric + Cleric $\mathrm{x}$ MoreIncome).

${ }^{69}$ We do not find strong evidence for differential treatment effects across ethnolinguistic divisions (i.e., Dari or Pashto speakers). On subjective feelings of poverty, we find that the cleric's presence crowds out people who contribute despite feeling poor, which is consistent with crowding out of intrinsic motivation among the most motivated. However,
} 


\section{Selection and Crowding Out}

The distribution of contributions in Figure 1 suggests, but does not show, that appeals by religious authorities generate selection (in) and crowding out. To show selection, we need to see that the subjects who would not have contributed to a civilian would do so if asked by a cleric. To show crowding out, we need to see that subjects who would have contributed larger amounts to a civilian would reduce their contribution to a cleric. This subsection will describe a simple exercise to simulate this counterfactual.

We regress the amount contributed in the Civilian condition on the control variables used in our core models. Based on these estimates, we then generate Predicted Contribution: the amount that all subjects in the experiment would have contributed if they were in the Civilian condition. Subtracting actual amount contributed (Average Contribution) from Predicted Contribution, we generate Prediction Error, a crude estimate of the effect of the treatment on each individual. A positive Prediction Error indicates that the individual increased his contribution under the treatment; a negative prediction error suggests the opposite.

Table 4 and Figure 2a show the results of this analysis. ${ }^{70}$ Since $10 \mathrm{AFN}$ is the lowest contribution level, we identify subjects who would have been Low Contributors and High Contributors to the civilian solicitor based on whether their Predicted Contribution is

the sample is highly unbalanced since so few subjects do not feel poor. Results available upon request.

${ }^{70}$ Average Prediction Error in the Civilian condition is reassuringly zero, while it is positive and significant for both the Cleric (3.39 AFN, $\mathrm{p}=0.03$ ), and Cleric + Scripture (9.74 AFN, $\mathrm{p}<0.01$ ), suggesting that both treatments increased contribution. 
above or below 10 AFN. ${ }^{71}$ Reassuringly, in the Civilian condition (Panel A), Prediction Error is not statistically different from zero regardless of whether we are looking at all subjects, Low Contributors, or High Contributors. However, Prediction Error in the Cleric condition (Panel B) is $3.39\left(\mathrm{p}^{=0.03)}\right.$ when we look at all subjects, $10.21(\mathrm{p}<0.01)$ for the Low Contributors and -3.82 for the High Contributors $\left(p^{=}=0.10\right)$. The positive effect of Cleric on Low Contributors and the negative effect on High Contributors (Figure 2a, dark gray bars) indicate that positional authority indeed induces both selection and crowding out. $^{72}$

We now return to the investigation we started in Table 3 Panels B and C: how does income and education mediate the influence of religious authorities? Looking at the Prediction Error in the Cleric condition across demographic groups (Table 4, Panel B), we can see that there is little heterogeneity in the selection effect: all Low Contributors are now giving about $10 \mathrm{AFN}$ more when asked by the cleric, regardless of income and education (Figures $2 \mathrm{~b} \& 2 \mathrm{c}, 1^{\text {st }} \& 3^{\text {rd }}$ dark gray bars). ${ }^{73}$ Crowding out, however, does appear to depend on demographics. Again, income does not appear to make a large difference here: High Contributors of both income categories appear to react negatively to the cleric (Figure $2 \mathrm{~b}$,

\footnotetext{
${ }^{71}$ The results are qualitatively similar if we use $15 \mathrm{AFN}$ or $20 \mathrm{AFN}$ as the threshold. Since these are predicted amounts, no subject was predicted to contribute exactly 10 AFN.

${ }^{72}$ Studies in social influence (e.g., Jones and Linardi 2014) find that being observed reduces giving among the more generous and increases it among the less generous.

${ }^{73}$ Contributing less than $10 \mathrm{AFN}$ is basically not contributing, though we refer to them as low contributors. Recall that five subjects (out of 305) contributed their own cash, enabling contributions lower than $10 \mathrm{AFN}$ in the data.
} 
$2^{\text {nd }} \& 4^{\text {th }}$ dark gray bars). On the other hand, while High Contributors with no formal education do not object to the cleric, those with formal education are reducing their contributions significantly $\left(0.72 \mathrm{AFN}\right.$ vs. $-6.66 \mathrm{AFN}$, Figure $2 \mathrm{c}, 2^{\text {nd }} \& 4^{\text {th }}$ dark gray bars $) .^{74}$

\section{Counteracting Crowding Out: Cleric + Scripture}

The main effect of the cleric's presence is to induce contributions from some subjects who otherwise would not give, but at the expense of crowding out the contributions of high contributors. This backlash appears to be driven by the formally educated. We next investigate whether the cleric's use of scripture can overcome the limitations of positional religious authority.

Returning to Table 2 and Figure 1, we see that Cleric + Scripture significantly improves the intensive margin without decreasing the large gains in the extensive margin that had been achieved in the Cleric condition, bringing a significant gain to the average contribution (22.38 AFN, p<0.01, Table 2 Panel C). This is confirmed by the light gray bars in the histogram in Figure 1: the frequency of large contributions (>20 AFN) not only recovered but even rose above the Civilian condition (17\% to $30 \%)$.

The increase in the intensive margin $(8.47, \mathrm{p}<0.05)$ and the average contributions $(6.85, \mathrm{p}<0.06)$ are confirmed through regression models in Table 5 (Panel A). Table 5 Panels B and C interacts the treatment dummy with More Income and Formal Education, as in Table 3. Again, though none of the interaction terms themselves is significant (Appendix Table 2), the linear combinations suggest that the increase in the intensive margin is only significant for subjects with More Income (14.63, p<0.01) and Formal

\footnotetext{
${ }^{74}$ The difference, however, is not statistically significant at conventional levels $(p=0.12)$.
} 
Education (12.68, p<0.01). The finding that those with above median income are able to increase their giving suggests that there is indeed some meaningful heterogeneity in income even among the very poor.

More importantly, the increase in the intensive margin among the educated suggests that scripture may be able to overcome the formally educated High Contributors' resistance to religious authority. ${ }^{75}$ Using the counterfactual simulation discussed earlier, we can see that in the Cleric + Scripture condition, Prediction Error for formally educated High Contributors is now no longer negative $\left(0.38, \mathrm{p}^{=0.91)} .^{76}\right.$ This suggests that the cleric's recitation of relevant scriptural quotes can overcome the opposition of those who are motivated to contribute to public goods but are unreceptive to being led by religious authority.

\section{Discussion}

In this section, we review our empirical results and tie them to our theoretical discussion of the two potential sources of a clergy's influence: imposition of human authority or affiliation with powers that are "not of this world." The results support three core arguments, which we review below. We then raise the issue of the external validity of our arguments and identify scope conditions that should guide the application of our framework in future work.

${ }^{75}$ See Table 4 Panel $\mathrm{B}$ and the $4^{\text {th }}$ dark gray bar in Figure 2c.

${ }^{76}$ This can also be seen in Figure 2c. Note that while the $4^{\text {th }}$ dark gray bar is significantly negative $(-6.66, \mathrm{p}<0.01)$, the $4^{\text {th }}$ light gray bar is close to zero.

${ }^{77}$ Olson 2009, 375. 
First, adherents to the faith see the cleric as a human authority, and not as an associate of the omnipresent. As in other studies, imposition of human authority increases compliance to requests among those who are unmotivated (Low Contributors), but also crowds out intrinsic motivation of the more motivated (High Contributors). In our context, this reaction may have arisen from grudging compliance to sadaqah, an understood Islamic norm that allows believers leeway in their choice of contribution, which the solicitor's clerical garb made salient. It is consistent with legalism in religion and shares similarities to employees' bridling against imposition of control in the firm. If the presence of the cleric had reminded subjects that "God is watching", we would not expect a decrease in conditional contribution to accompany the increase in the propensity to contribute, for this would suggest that while God can observe whether you give, he apparently cannot count.

Second, the authority of scripture counteracts this legalistic response. Its addition to the cleric's solicitation restores the contribution level of the High Contributors while nudging Low Contributors not only to contribute, but also to increase the amount. It appears that scripture, which is held in high regard by Muslims because it is thought to have been given directly by God to people for the purpose of clarifying the right way to live (Qur'an 10:37), may act as a justification for the cleric's interference or a reminder that God is watching and rewarding generous behavior. ${ }^{78}$

Third, the results show that the backlash against religious authority is driven by those who are formally educated, but that this resistance can be overcome by a rhetorical

\footnotetext{
${ }^{78}$ In Islamic sacred texts, giving to charitable causes is linked to being rewarded with sustenance, material blessing, physical healing, avoidance of deserved negative consequences of one's actions, etc. (Al-Ali 2003).
} 
tool often employed by religious authorities: verbatim quotations of scripture. This has important implications for future study of the role of religious authority in social and political mobilization, and may relate to why fundamentalists groups have fought against the spread of formal education in Afghanistan.

Our theoretical framework that separates the power derived from a religious leader's position as an authority and his use of scripture or other direct references to the supernatural may be applicable to other religious and geographic contexts. Consider Djupe and Gwiasda's study of American evangelical Christians' reaction to public policy against which they are predisposed: governmental pro-environmental policies. ${ }^{79}$ When told that a reverend leader (instead of just a leader) supported the position, evangelicals' support for the controversial position actually decreased. However, when evangelicals were told that the reverend leader had arrived at that position after careful reflection on scripture, their support for the policies increased dramatically, showing that elites are judged on their decision-making processes. ${ }^{80}$ This example illustrates that even in a setting that is very different from our experiment, a backlash can be observed when positional authority is wielded without the backing of scriptural authority. The two authorities had to be combined in order to effect a change.

In considering how to generalize our framework and findings beyond this experiment, we note that there exists a relevant norm in this context that religious authority and scripture can cue, which then guides the faithful's behavioral choices. In our experiment, religious authority cues self-sacrifice through sadaqah, a norm allowing

\footnotetext{
${ }^{79}$ Djupe and Gwiasda 2010.

${ }^{80}$ Djupe and Calfano 2009.
} 
freedom in choices over contributions, and positional and scriptural authority affect those choices in different ways. This is less of a restrictive condition than one might think, however, as there are many other norms in Islam (and other religions) that exist and through which authority can influence relevant behavior: the sanctity of human life (Qur'an 5:32, 17:33), honesty (Qur'an 26:181-183), forgiveness (Qur'an 42:37), or the use of violence (Qur'an 4:74), to list a few. ${ }^{81}$ While we have shown evidence of the effects of religious authority when such a norm exists, this may not be a necessary condition.

Another issue raised by our findings on the cleric's ability to counteract the crowding out effect is the application of our argument about scripture being influential on behavior. The key question here is, where does authority reside for the believer? Adherents to the faith must hold their scripture as authoritative or it is unlikely to have any power. "Religions of the Book" - Judaism, Islam, and Christianity - meet this criterion, while this distinction is likely to be less relevant for religions - like Hinduism and Buddhism - that do not view scripture as "revealing divine, eternal truths and laws.",

\footnotetext{
${ }^{81}$ A reasonable assumption, reinforced by recent evidence from survey experiments conducted in Egypt (Jamal, et al. 2014), is that the impact of scripture-based appeals on opinions may vary depending on the issue in question, particularly how easily a religious value or norm can be applied to a given political context (Djupe and Calfano 2013). ${ }^{82}$ Davis and Robinson 2012, 11. Even within the Abrahamic faiths there is variation in the degree to which scripture is authoritative for believers (e.g., Catholics and Protestants), and so our emphasis on scripture's authority as distinct from clerical authority will be more or less salient as a result.
} 
Another aspect of external validity here has to do with critiques of the artificiality of experimental settings and intervention. We believe that our study holds up well to this particular line of criticism. Our subjects were taken from the population that we care about observing - low income Afghans - and were enumerated in a neighborhood setting familiar to our subjects. ${ }^{83}$ This is in stark contrast to other studies, particularly in the U.S., which often use university students as their subjects and cannot readily generalize their findings beyond that sample. ${ }^{84}$ We obtain a meaningful measure of the effect of our intervention by asking our subjects for a real sacrifice: contribute part of their day's wages to the hospital. More importantly, our intervention was delivered and designed in cooperation with an actual cleric, taking advantage of his relevant professional expertise and everyday experience in communicating to believers. As such, our causal estimate of the effect of positional religious authority holds constant all the subtle cues of body and voice of people who select into the profession, characteristics that are impossible to define but are nevertheless integral to a leader's influence.

The aforementioned advantages of our study notwithstanding, a fruitful avenue for future research would be further experimental work on religious authority's effects on forms of social and political mobilization that do not involve monetary contributions, as the conditions under which clergy can influence individuals' political behavior are still far from

\footnotetext{
${ }^{83}$ One might argue that a more ideal setting to conduct our experiment might have been in or around a mosque, making use of actual gatherings of believers and embedding our treatments into the normal context of interaction between religious authority and participants, but such a design would forego a baseline (non-primed) estimate of behavior. ${ }^{84}$ For example, see Djupe and Calfano 2009, Djupe and Calfano 2013.
} 
settled in the literature. ${ }^{85}$ To take just one example, of growing importance in the wake of the Arab Spring and increased frequency of elections across the Muslim world is the role of religious authority in electoral politics. While religious identity has been studied as a determinant of voting decisions, ${ }^{86}$ the effects of religious authority on vote choice is still poorly understood. It also would be useful to experimentally contrast religious authority with specific types of civilian authority, as well as to experiment with a different population (less poor, or with a larger variance in income). Finally, it would build on our knowledge to extend this framework to other administratively and bureaucratically weak states where religion exercises an historically strong influence in society, such as parts of Africa or Latin America.

\section{Conclusion}

In an experiment involving an actual Muslim cleric, we test the effect that a cleric's positional authority has on contributions to a public good by low-income Muslim men. Our choice of a randomized experimental design lends confidence to our estimates of these effects over and above observational studies, quasi-experimental studies, or even ones that employ near-random assignment, at least in terms of their internal validity. ${ }^{87}$ Moreover, our choice of setting, activity, and subject recruitment in the experiment addresses common concerns about external validity.

\footnotetext{
${ }^{85}$ Djupe and Gilbert 2009.

${ }^{86}$ De La O and Rodden 2008, Claassen and Povtak 2010.

${ }^{87}$ Paluck and Green 2009.
} 
We find that, holding constant our “civilian's” perceived educational and charismatic qualities, the donning of clerical garments induces dramatic changes in subjects' willingness to support a public good. In particular, the cleric's presence brings in new givers who contribute the minimum and crowds out the generous contributors. This crowding out is driven by those who are formally educated. The induced effects are consistent both with a literature that shows people obeying authority even when it is costly, and with studies showing that people bridle against that authority by reducing their contributions along certain dimensions. In this setting, this behavior is probably best interpreted as a form of religious legalism, and shows a possible negative effect of positional authority on behavior. We find that the cleric can correct for this crowding out and overcome the resistance of the educated with scripture, which cues an idea well established in the experimental literature that "God is watching," and in this case cues behavior that demonstrates generosity, possibly in pursuit of rewards from the supernatural.

Our contributions to the broader literature on religion's effect on behavior are several. First, while other studies have investigated the effects of priming religion or even clerical authority within one's congregation, we investigate religious authority's effects on those outside one's congregation (direct action), a much less studied context and a harder test of the power of religious authority. Moreover, we supply arguably cleaner estimates of the treatment effects, as well as more reliable evidence of this approach's promise, by using an actual religious authority in the cleric.

Second, we identify and test competing mechanisms through which religious authority could affect political and social mobilization, particularly support for public goods provision. We go substantially beyond simply showing that the cleric's identity has an effect 
on behavior. We are able to show exactly how religious authority affects voluntary contribution to the public good and that the cleric has different effects across the distribution of subjects. All of this has important policy implications. For example, development practitioners, trying to enhance "good governance" outcomes in weak states, seek "to implement interventions designed to increase a community's collective capacity." This is the first study to provide evidence showing how religious authority affects such capacity in exactly the environment of interest for this policy domain.

Our explanation of the experimental results takes seriously the fact that religion has a powerful effect on behavior, especially where it can be a tool that elites use to outbid one another $^{89}$ and where elites act as issue and interest entrepreneurs in mobilizing people for collective action on the basis of religious identity. ${ }^{90}$ Besides the implications for the literature on public goods provision, elites' use of religious authority for mobilization is important in other areas of politics. One is the production of violence, such as recruitment to terrorist organizations ${ }^{91}$ and suicide terrorism, ${ }^{92}$ or even 'de-radicalization' of terrorists using religious authority; ${ }^{93}$ we know extremely little about how that authority affects behavior in either case. Our findings show that the way in which religion generally, and religious authority in particular, affects social and political mobilization is underspecified in

\footnotetext{
${ }^{88}$ Humphreys and Weinstein 2009, 371.

${ }^{89}$ Toft 2007.

${ }^{90}$ Wald, et al. 2005, 129, Patel 2007.

${ }^{91}$ Hegghammer 2013, 10-11.

${ }^{92}$ Berman and Laitin 2008, Berman 2009.

${ }^{93}$ White and Wright 2007, Raddatz and Netter 2010, Stern 2010.
} 
current scholarship and needs much more careful empirical testing for us to know how positional and scriptural authority affect behavior in different contexts. 


\section{REFERENCES}

Al-Ali, Ahmad. 2003. Beauty of Charity. Dar es Salaam, Tanzania: Dar-Tabligh.

Al-Kadhimi, Mustafa. 2013. "Friday Sermons Used to Incite at Iraqi Mosques." AlMonitor, August 2013.

Al Qardawi, Yusuf. 1999. A Comparative Study of Zakah, Regulations and Philosophy in the Light of Qur'an and Sunnah. Translated by Monzer Kahf. Vol. 2. Jeddah, Saudi Arabia: Scientific Publishing Centre.

Asch, Solomon E. 1952. Social Psychology. New York: Prentice-Hall.

Bandura, Albert. 1986. "Social Foundations of Thought and Action: A Social-Cognitive View." Englewood Cliffs, NJ: Prentice Hall.

Barfield, Thomas J. 2010. Afghanistan: A Cultural and Political History. Princeton, NJ: Princeton University Press.

Bateson, Melissa, Daniel Nettle, and Gilbert Roberts. 2006. "Cues of Being Watched Enhance Cooperation in a Real-World Setting." Biology Letters 2: 412-14.

Beath, Andrew, Fotini Christia, and Ruben Enikolopov. 2013. "Empowering Women through Development Aid: Evidence from a Field Experiment in Afghanistan." American Political Science Review 107: 540-57.

Becker, Jo, and Scott Shane. 2012. "Secret 'Kill List' Proves a Test of Obama's Principles and Will." The New York Times, May 29, 2012.

Bekkers, René, and Pamela Wiepking. 2011. "Who Gives? A Literature Review of Predictors of Charitable Giving Part One: Religion, Education, Age and Socialisation." Voluntary Sector Review 2: 337-65.

Bell, James. 2012. "The World's Muslims: Unity and Diversity." In Secondary The World's Muslims: Unity and Diversity, ed Secondary —. Washington, DC. Reprint, Reprint.

Benjamin, Daniel J., James J. Choi, and Geoffrey W. Fisher. 2010. "Religious Identity and Economic Behavior." NBER Working Paper No. 15925.

Berman, Eli. 2009. Radical, Religious and Violent: The New Economics of Terrorism. Cambridge, MA: MIT Press.

Berman, Eli, and David D. Laitin. 2008. "Religion, Terrorism and Public Goods: Testing the Club Model." Journal of Public Economics 92: 1942-67.

Blaydes, Lisa, and Drew A. Linzer. 2008. "The Political Economy of Women's Support for Fundamentalist Islam." World Politics 60: 576-609.

Bueno de Mesquita, Ethan. 2005. "The Quality of Terror." American Journal of Political Science 49: 515-30.

Burnham, Terrance C., and Brian Hare. 2007. "Engineering Human Cooperation: Does Involuntary Neural Activation Increase Public Goods Contributions?". Human Nature 18: 88-108.

Calfano, Brian Robert, and Philip Paolino. 2010. "An Alan Keyes Effect? Examining Anti-Black Sentiment among White Evangelicals." Political Behavior 32: 133-56.

Carpenter, Thomas P, and Margaret A Marshall. 2009. "An Examination of Religious Priming and Intrinsic Religious Motivation in the Moral Hypocrisy Paradigm." Journal for the Scientific Study of Religion 48: 386-93.

Chhibber, Pradeep, and Jasjeet S. Sekhon. 2015. "The Asymmetric Role of Religious Appeals in India." University of California, Berkeley, April 13, 2015. 
Claassen, Ryan L., and Andrew Povtak. 2010. "The Christian Right Thesis: Explaining Longitudinal Change in Participation among Evangelical Christians." Journal of Politics 72: 2-15.

Davis, Nancy J., and Robert V. Robinson. 2012. Claiming Society for God: Religious Movements and Social Welfare. Bloomington, IN: Indiana University Press.

De La O, Ana L., and Jonathan Rodden. 2008. "Does Religion Distract the Poor? Income and Issue Voting around the World.". Comparative Political Studies 41: 437-76.

Delamontagne, R. Georges. 2010. "Religiosity and Hate Groups: An Exploratory and Descriptive Correlational Study." Journal of Religion \& Society 12: 1-19.

Djupe, Paul A., and Brian R. Calfano. 2009. "Justification Not by Faith Alone: Clergy Generating Trust and Certainty by Revealing Thought." Politics \& Religion 2: 1-30.

Djupe, Paul A., and Christopher P. Gilbert. 2009. The Political Influence of Churches. New York: Cambridge University Press.

—. 2003. The Prophetic Pulpit: Clergy, Churches, and Communities in American Politics. Lanham, MD: Rowman and Littlefield.

Djupe, Paul A., and Gregory W. Gwiasda. 2010. "Evangelizing the Environment: Decision Process Effects in Political Persuasion." Journal for the Scientific Study of Religion 49: 73-86.

Djupe, Paul A., and Patrick K. Hunt. 2009. "Beyond the Lynn White Thesis: Congregational Effects on Environmental Concern." Journal for the Scientific Study of Religion 48: 670-86.

Djupe, Paul, and Brian Calfano. 2013. God Talk: Experimenting with the Religious Causes of Public Opinion. Philadelphia, PA: Temple University Press.

Druckman, James N. 2001. "On the Limits of Framing Effects: Who Can Frame." Journal of Politics 63: 1041-66.

Dubrovsky, Vitaly J., Sara Kiesler, and Beheruz N. Sethna. 1991. "The Equalization Phenomenon: Status Effects in Computer-Mediated and Face-to-Face DecisionMaking Groups." Human-Computer Interaction 6: 119-46.

El-Menouar, Yasemin. 2014. "The Five Dimensions of Muslim Religiosity: Results of an Empirical Study." Methods, data, analyses: A Journal for Quantitative Methods and Survey Methodology 8: 53-78.

Engel, Christoph. 2011. "Dictator Games: A Meta Study." Experimental Economics 14: 583-610.

Ernst, Douglas. 2015. "Al Qaeda: Top Cleric of Yemeni Branch Killed in Drone Strike." The Washington Times, April 14, 2015.

Falk, Armin, and Michael Kosfeld. 2006. "The Hidden Costs of Control." American Economic Review 96: 1611-30.

Fathi, Asghar. 1981. "The Islamic Pulpit as a Medium of Political Communication." Journal for the Scientific Study of Religion 20: 163-72.

Fearon, James D., Macartan Humphreys, and Jeremy M. Weinstein. 2009. "Can Development Aid Contribute to Social Cohesion after Civil War? Evidence from a Field Experiment in Post-Conflict Liberia." American Economic Review: Papers \& Proceedings 99: 287-91. 
Fetzer, Joel S. 2001. "Shaping Pacifism: The Role of the Local Anabaptist Pastor." In Christian Clergy in American Politics, eds. Sue E. S. Crawford and Laura R. Olson. Baltimore, MD: Johns Hopkins University Press. 177-87.

Frey, Bruno S. 1993. "Does Monitoring Increase Work Effort? The Rivalry with Trust and Loyalty." Economic Inquiry 31: 663-70.

Gervais, Wil M., and Ara Norenzayan. 2012. "Like a Camera in the Sky? Thinking About God Increases Public Self-Awareness and Socially Desirable Responding." Journal of Experimental Social Psychology 48: 298-302.

Grossman, Guy, and Delia Baldassarri. 2012. "The Impact of Elections on Cooperation: Evidence from a Lab-in-the-Field Experiment in Uganda." American Journal of Political Science 56: 964-85.

Guth, James L., John C. Green, Corwin E. Smidt, Lyman A. Kellstedt, and Margaret M. Poloma. 1997. The Bully Pulpit: The Politics of Protestant Clergy. Lawrence, KS: University Press of Kansas.

Haley, Kevin J., and Daniel M. T. Fessler. 2005. "Nobody's Watching? Subtle Cues Affect Generosity in an Anonymous Economic Game." Evolution and Human Behavior 26: 245-56.

Hegghammer, Thomas. 2013. "Should I Stay or Should I Go? Explaining Variation in Western Jihadists' Choice between Domestic and Foreign Fighting." American Political Science Review 107: 1-15.

Hogan, Caelainn. 2014. "Muslim Clerics in Nigeria Advocate for Polio Vaccination and Mobilize Community." Washington Post, August 6.

Holmstrom, Bengt, and Paul Milgrom. 1991. "Multitask Principal-Agent Analyses: Incentive Contracts, Asset Ownership, and Job Design." Journal of Law, Economics, \& Organization 7: 24-52.

Humphreys, Macartan, and Jeremy M. Weinstein. 2009. "Field Experiments and the Political Economy of Development." Annual Review of Political Science 12: $367-$ 78.

Iannaccone, Laurence R. 1988. "A Formal Model of Church and Sect." American Journal of Sociology 94: S241-S68.

Jamal, Amaney, Tarek Masoud, and Elizabeth Nugent. 2014. "Between Dictates and Dispensations: Experimental Evidence on Legitimacy and Policy Preferences." Princeton University and Harvard University, April 6.

Johnson, Megan K, Wade C Rowatt, and Jordan LaBouff. 2010. "Priming Christian Religious Concepts Increases Racial Prejudice." Social Psychological and Personality Science 1: 119-26.

Johnston, Patrick B., and Anoop K. Sarbahi. 2015. "The Impact of U.S. Drone Strikes on Terrorism in Pakistan." RAND Corporation and University of Minnesota, February 20, 2015.

Jones, Daniel, and Sera Linardi. 2014. "Wallflowers: Experimental Evidence of an Aversion to Standing Out." Management Science 60: 1757-71.

Kuklinski, James H., and Norman L. Hurley. 1996. "It's a Matter of Interpretation." In Political Persuasion and Attitude Change, eds. Diana C. Mutz, Richard A. Brody and Paul M. Sniderman. Ann Arbor: University of Michigan Press. 125-44. 
Lambarraa, Fatima, and Gerhard Riener. 2012. "On the Norms of Charitable Giving in Islam: A Field Experiment." Paper presented at the Courant Research Centre Discussion Papers.

Levitt, Matthew. 2006. Hamas: Politics, Charity, and Terrorism in the Service of Jihad. New Haven, CT: Yale University Press.

Linardi, Sera, Rebbeca Morton, Kai Ou, Xiangdong Qin, and Gumilang Sahadewo. 2015. "The Price of Religion: Experiments in Willingness to Bear Risk for Others in Islamic Communities." New York University, February 16, 2015.

Mazar, Nina, On Amir, and Dan Ariely. 2008. "The Dishonesty of Honest People: A Theory of Self-Concept Maintenance." Journal of marketing research 45: 633-44.

McCauley, John F. 2014. "Measuring and Reducing Religious Bias in Post-Conflict Zones: Evidence from Côte D'ivoire." Political Psychology 35: 267-89.

McClendon, Gwyneth, and Rachel Riedl. 2014. "Religion, Redistribution and Political Participation: Evidence from an Experiment in Nairobi, Kenya." Harvard University and Northwestern University, September 11, 2014.

Milgram, Stanley. 1974. Obedience to Authority. New York: Harper \& Row.

Mogelson, Luke. 2012. "Pacifists in the Cross-Fire: The Kabul Hospital That Treats All Sides." New York Times, May 18, 2012.

Nasir, Sani-Gwarzo, Gambo Aliyu, Inuwa Ya'u, Muktar Gadanya, Muktar Mohammad, Mahmud Zubair, and Samer S. El-Kamary. 2014. "From Intense Rejection to Advocacy: How Muslim Clerics Were Engaged in a Polio Eradication Initiative in Northern Nigeria." PLOS Medicine 11: 1-6.

Nohria, Nitin, and Robert G. Eccles. 1992. "Face-to-Face: Making Network Organizations Work." In Networks and Organizations: Structure, Form and Action, eds. Nitin Nohria and Robert G. Eccles. Boston: Harvard Business School Press.

Olson, Laura R. 2009. "Clergy and American Politics." In The Oxford Handbook of Religion and American Politics, eds. Corwin E. Smidt, Lyman A. Kellstedt and James L. Guth. Oxford, UK: Oxford University Press. 371-93.

- 2000. Filled with Spirit and Power: Protestant Clergy in Politics. Albany, NY: State University of New York Press.

Paluck, Elizabeth Levy, and Donald P. Green. 2009. "Prejudice Reduction: What Works? A Review and Assessment of Research and Practice." Annual Review of Psychology 60: 339-67.

Patel, David S. 2012. "Concealing to Reveal: The Informational Role of Islamic Dress." Rationality and Society 24: 295-323.

—. "Islam, Information, and Social Order: The Strategic Role of Religion in Muslim Societies." Dissertation, Stanford University, 2007.

Raddatz, Martha, and Sarah Netter. 2010. "Rehab for Terrorists: Pakistan Tries Reintegration Program on Teen Extremists." ABC News, December 31, 2010.

Rees, Tomas James. 2009. "Is Personal Insecurity a Cause of Cross-National Differences in the Intensity of Religious Belief?". Journal of Religion and Society 11: 1-24.

Rennie, Ruth. 2008. "State Building, Security, and Social Change in Afghanistan: Reflections on a Survey of the Afghan People." In Secondary State Building, Security, and Social Change in Afghanistan: Reflections on a Survey of the Afghan People, ed Secondary —. Reprint, Reprint. 
Robinson, Carin. 2010. "Cross-Cutting Messages and Political Tolerance: An Experiment Using Evangelical Protestants." Political Behavior 32: 495-515.

Sagioglou, Christina, and Matthias Forstmann. 2013. "Activating Christian Religious Concepts Increases Intolerance of Ambiguity and Judgment Certainty." Journal of Experimental Social Psychology 49: 933-39.

Schnedler, Wendelin, and Radovan Vadovic. 2011. "Legitimacy of Control." Journal of Economics \& Management Strategy 20: 985-1009.

Shariff, Azim F., and Ara Norenzayan. 2007. "God Is Watching You: Priming God Concepts Increases Prosocial Behavior in an Anonymous Economic Game." Psychological Science 18: 803-09.

Shariff, Azim F., Aiyana K. Willard, Teresa Andersen, and Ara Norenzayan. forthcoming. "Religious Priming: A Meta-Analysis with a Focus on Prosociality." Personality and Social Psychology Review.

Silverman, Dan, Joel Slemrod, and Neslihan Uler. 2014. "Distinguishing the Role of Authority 'in' and Authority 'To'." Journal of Public Economics 113: 32-42.

Smidt, Corwin E., ed. 2004. Pulpit and Politics: Clergy in American Politics at the Advent of the Millennium. Waco, TX: Baylor University Press.

Stern, Jessica. 2010. "Mind over Martyr: How to Deradicalize Islamist Extremists." Foreign Affairs 89: 95-108.

Tariq, Mohammad Osman, Najla Ayoubi, and Fazel Rabi Haqbeen. 2011. "Afghanistan in 2011: A Survey of the Afghan People." In Secondary Afghanistan in 2011: A Survey of the Afghan People, ed Secondary —. Kabul. Reprint, Reprint.

Toft, Monica. 2007. "Getting Religion? The Puzzling Case of Islam and Civil War." International Security 30: 97-131.

Wald, Kenneth D., Adam L. Silverman, and Kevin S. Fridy. 2005. "Making Sense of Religion in Political Life." Annual Review of Political Science 8: 121-43.

Watch, Human Rights. 2006. "Lessons in Terror: Attacks on Education in Afghanistan." In Secondary Lessons in Terror: Attacks on Education in Afghanistan, ed Secondary —. Reprint, Reprint.

White, Josh, and Robin Wright. 2007. "After Guntanamo, 'Reintegration' for Saudis." Washington Post, December 10, 2007. 
Figure 1. Amount Contributed to EMERGENCY Hospital (All Subjects)

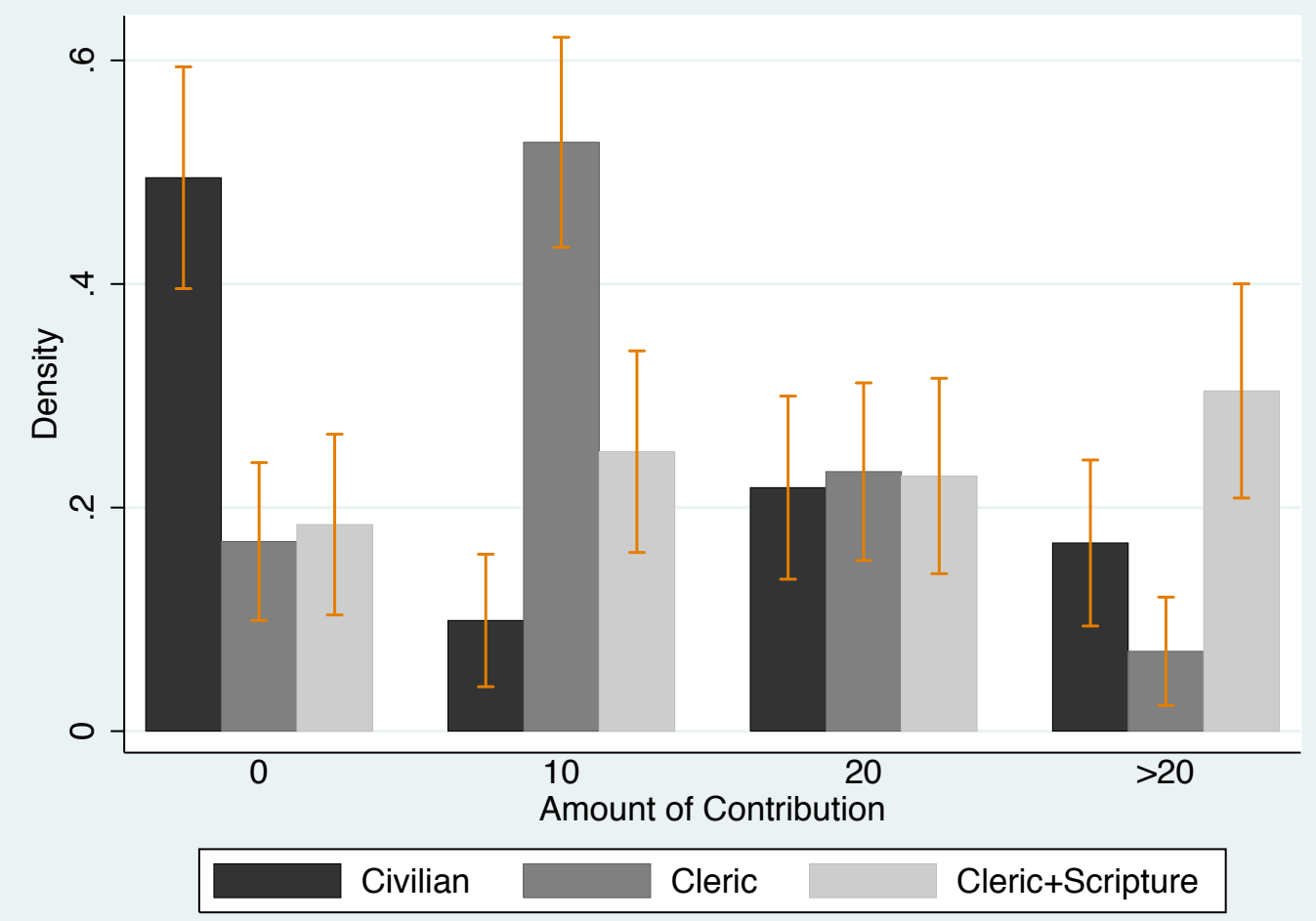


Figure 2a. Prediction Errors for Low Contributors ( $<10$ AFN) and High Contributors $(>=10$ AFN) in Civilian, Cleric, and Cleric + Scripture Conditions

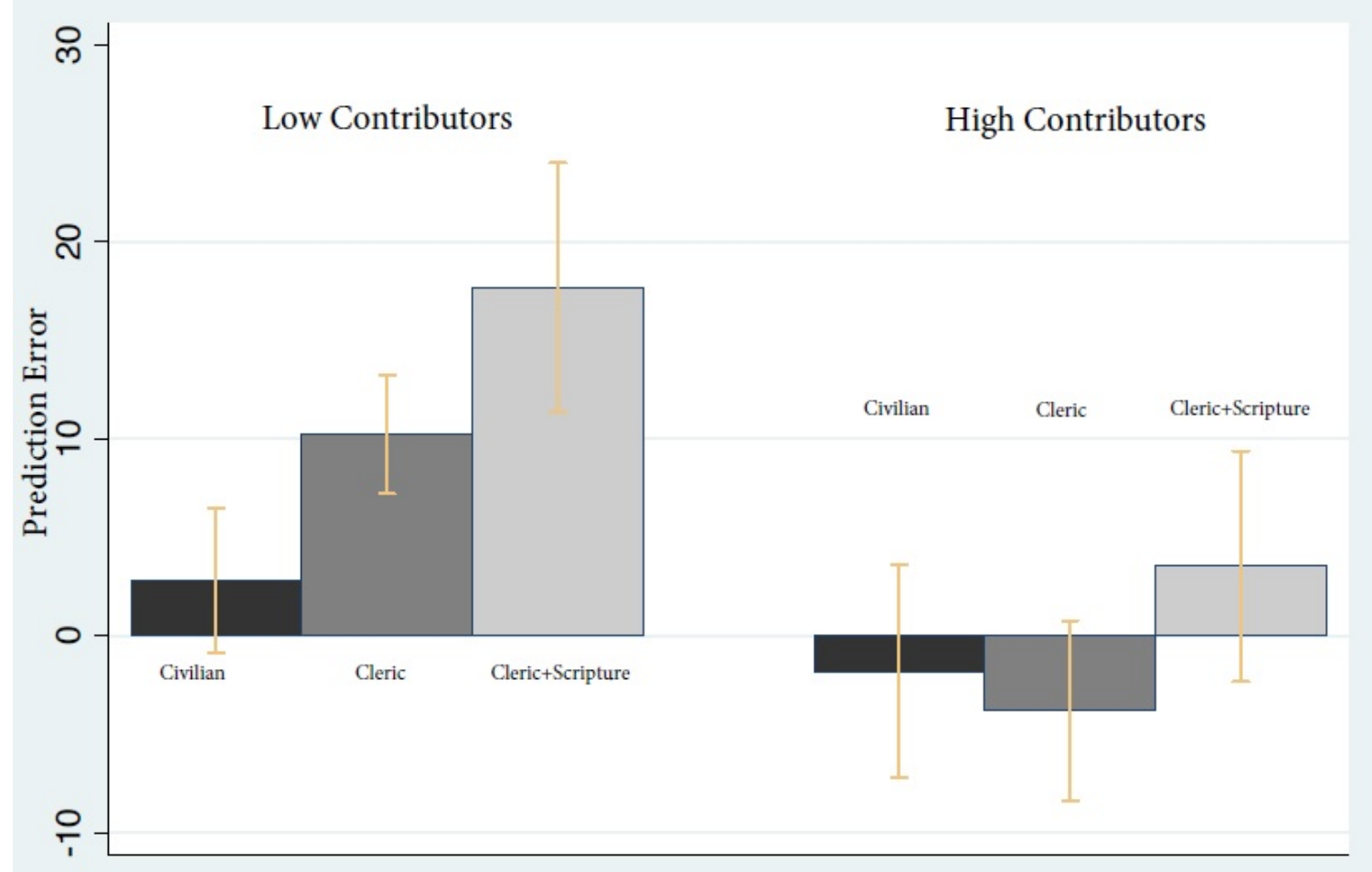


Figure 2b. Prediction Errors for Low Contributors ( $<10$ AFN) and High Contributors $(>=10$ AFN) in Civilian, Cleric, and Cleric + Scripture Conditions, by Less Income and More Income

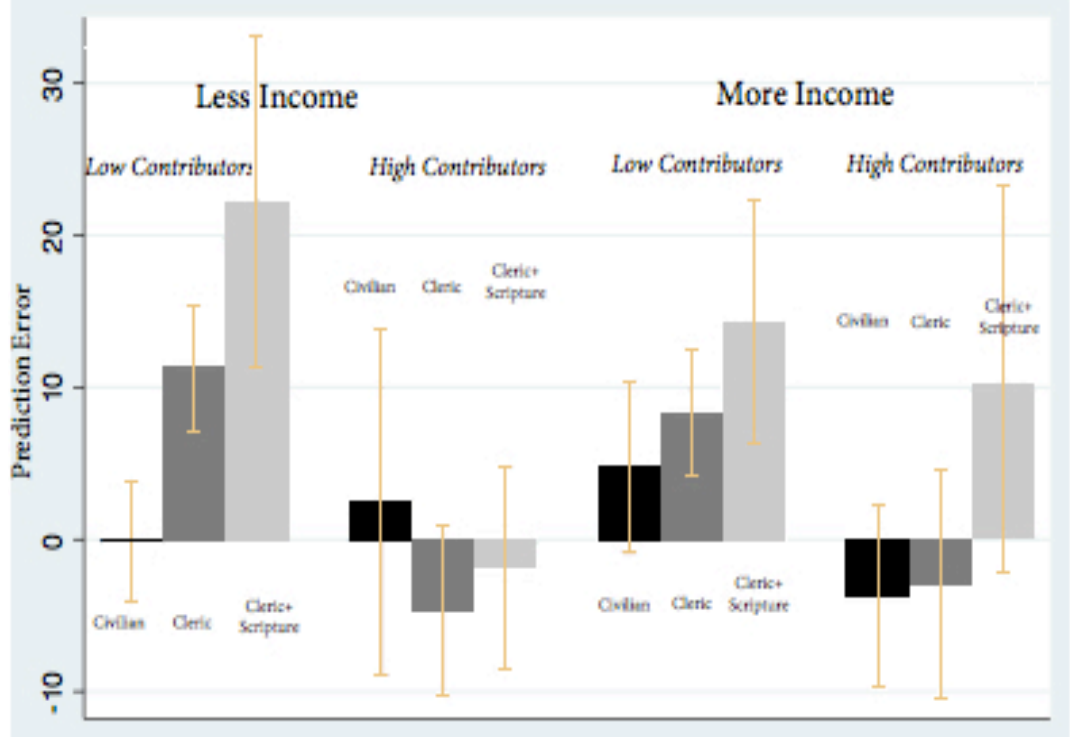


Figure 2c. Prediction Errors for Low Contributors ( $<10 \mathrm{AFN})$ and High Contributors $(>=10 \mathrm{AFN})$ in Civilian, Cleric, and Cleric + Scripture Conditions, by No Formal Education and Formal Education

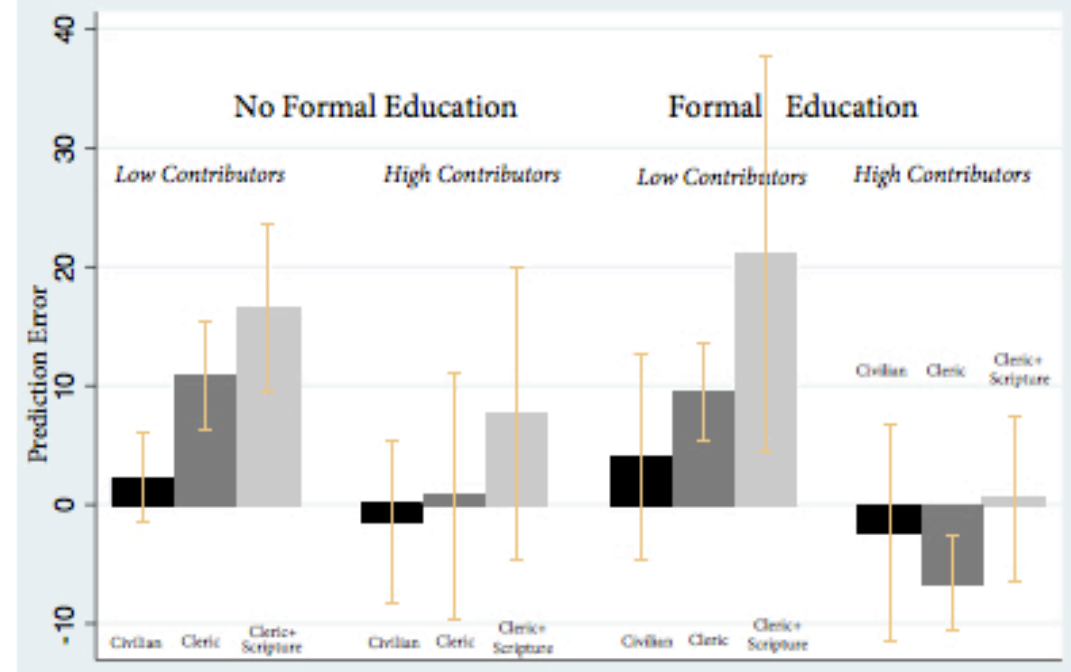


Table 1. Summary Statistics on Demographics (All Treatments)

\begin{tabular}{lccccc}
\hline Variable & Obs & Mean & Std. Dev. & Min & Max \\
\hline Age & & & & \\
Married & 305 & 30.31 & 12.47 & 18 & 88 \\
Language count & 305 & 0.72 & 0.45 & 0 & 1 \\
Pashtun ethnicity & 305 & 1.62 & 0.66 & 1 & 4 \\
No education at all & 305 & 0.31 & 0.46 & 0 & 1 \\
Formal education & 305 & 0.53 & 0.50 & 0 & 1 \\
Qur'anic education & 305 & 0.42 & 0.49 & 0 & 1 \\
Years of education & 305 & 0.05 & 0.22 & 0 & 1 \\
\# years in occupation & 131 & 8.00 & 3.56 & 1 & 15 \\
\# days worked last week & 302 & 9.20 & 8.42 & 0 & 45 \\
Feel poor & 305 & 2.60 & 1.40 & 0 & 7 \\
Monthly income & 305 & 0.72 & 0.45 & 0 & 1 \\
\hline
\end{tabular}


Table 2. Contribution Summary Statistics by Treatment Condition

\begin{tabular}{|c|c|c|c|c|c|}
\hline Variable & Obs & Mean & Std. Dev. & Min & $\operatorname{Max}$ \\
\hline \multicolumn{6}{|l|}{$\begin{array}{l}\text { Civilian } \\
\text { Number of sessions: } 16\end{array}$} \\
\hline Contribute & 101 & 0.50 & 0.50 & () & 1 \\
\hline Amount | Contribute & 51 & 26.63 & 19.79 & 3 & 100 \\
\hline Average Contribution & 101 & 13.45 & 19.36 & 0 & 100 \\
\hline \multicolumn{6}{|l|}{$\begin{array}{l}\text { Cleric } \\
\text { Number of sessions: } 19\end{array}$} \\
\hline Contribute & 112 & 0.83 & 0.38 & 0 & 1 \\
\hline Amount | Contribute & 93 & 16.13 & 12.69 & 10 & 100 \\
\hline Average Contribution & 112 & 13.39 & 13.05 & 0 & 100 \\
\hline \multicolumn{6}{|l|}{$\begin{array}{l}\text { Cleric }+ \text { Scripture } \\
\text { Number of sessions: } 16\end{array}$} \\
\hline Contribute & 92 & 0.82 & 0.39 & 0 & 1 \\
\hline Amount | Contribute & 75 & 27.45 & 22.78 & 5 & 150 \\
\hline Average Contribution & 92 & 22.38 & 23.16 & () & 150 \\
\hline
\end{tabular}


Table 3. Summary of Cleric Treatment Effects

\begin{tabular}{cccc}
\hline Effect of Cleric on & Contribute & Amount $\mid$ Contribute & Average Contribution \\
\hline PANEL A & & & \\
\hline All & $0.41^{* * *}$ & $-9.88^{* *}$ & 2.43 \\
& $(0.08)$ & $(3.76)$ & $(2.52)$ \\
Observations & 202 & 137 & 202 \\
R-squared & 0.26 & 0.26 & 0.14 \\
\hline PANEL B & & & 1.73 \\
\hline Less Income & $0.43^{* * *}$ & $-9.70^{*}$ & $(3.88)$ \\
& $(0.10)$ & $(5.60)$ & 2.01 \\
More Income & $0.35^{* * *}$ & $-9.43^{* *}$ & $(3.28)$ \\
& $(0.10)$ & $(4.23)$ & 210 \\
Observations & 210 & 142 & 0.13 \\
R-squared & 0.24 & 0.27 & \\
\hline PANEL C & & & 3.32 \\
\hline No Formal Education & $0.32^{* * *}$ & -6.66 & $(3.63)$ \\
& $(0.09)$ & $(4.93)$ & -0.11 \\
Formal Education & $0.47^{* * *}$ & $-14.14^{* *}$ & $(3.84)$ \\
& $(0.11)$ & $(5.27)$ & 210 \\
Observations & 210 & 142 & 0.13 \\
R-squared & 0.24 & 0.28 &
\end{tabular}

Note: Robust standard errors clustered on sessions in parentheses.

Extensive controls and enumerator FE included - see Appendix Table 1 for full results. ${ }^{* * *} \mathrm{p}<0.01,{ }^{* *} \mathrm{p}<0.05,{ }^{*} \mathrm{p}<0.1$ 
Table 4. Prediction Errors in the Civilian and Cleric Treatment Conditions

\begin{tabular}{lcccc}
\hline PANEL A & Obs & Mean & SD & p-value \\
\hline CIVILIAN & & & & \\
\hline Average Contribution & 101 & 13.45 & 19.36 & 0.00 \\
Predicted Contribution & 95 & 13.24 & 9.08 & 0.00 \\
Prediction Error & 95 & 0.00 & 17.23 & 1.00 \\
Low Contributors & 37 & 2.81 & 10.99 & 0.13 \\
High Contributors & 58 & -1.80 & 20.13 & 0.50
\end{tabular}

Low Contributors:

$\begin{array}{rcccc}\text { Less Income } & 15 & -0.11 & 7.18 & 0.95 \\ \text { More Income } & 22 & 4.81 & 12.75 & 0.09 \\ \text { No Formal Education } & 24 & 2.20 & 8.92 & 0.24 \\ \text { Formal Education } & 13 & 3.95 & 14.42 & 0.34\end{array}$

High Contributors:

\begin{tabular}{|c|c|c|c|c|}
\hline Less Income & 18 & 2.51 & 22.97 & 0.65 \\
\hline More Income & 40 & -3.73 & 18.70 & 0.21 \\
\hline No Formal Education & 36 & -1.43 & 20.03 & 0.67 \\
\hline Formal Education & 22 & -2.40 & 20.75 & 0.59 \\
\hline \multicolumn{5}{|l|}{ PANEL B } \\
\hline \multicolumn{5}{|l|}{ CLERIC } \\
\hline Average Contribution & 112 & 13.39 & 13.05 & 0.00 \\
\hline Predicted Contribution & 107 & 10.06 & 9.42 & 0.00 \\
\hline Prediction Error & 107 & 3.39 & 15.60 & 0.03 \\
\hline Low Contributors & 55 & 10.21 & 11.14 & 0.00 \\
\hline High Contributors & 52 & -3.82 & 16.46 & 0.10 \\
\hline \multicolumn{5}{|l|}{ Low Contributors: } \\
\hline Less Income & 35 & 11.26 & 12.24 & 0.00 \\
\hline More Income & 20 & 8.37 & 8.91 & 0.00 \\
\hline No Formal Education & 30 & 10.80 & 12.17 & 0.00 \\
\hline Formal Education & 25 & 9.50 & 9.97 & 0.00 \\
\hline \multicolumn{5}{|l|}{ High Contributors: } \\
\hline Less Income & 25 & -4.68 & 13.47 & 0.10 \\
\hline More Income & 27 & -3.03 & 19.04 & 0.42 \\
\hline No Formal Education & 20 & 0.72 & 22.26 & 0.89 \\
\hline Formal Education & 32 & -6.66 & 10.98 & 0.00 \\
\hline
\end{tabular}


Table 5. Summary of Cleric+Scripture Treatment Effects

\begin{tabular}{|c|c|c|c|}
\hline $\begin{array}{c}\text { Effect of } \\
\text { Cleric }+ \text { Scripture on }\end{array}$ & Contribute & Contribute & Average Contribution \\
\hline \multicolumn{4}{|l|}{ PANEL A } \\
\hline \multirow[t]{2}{*}{ All } & -0.07 & $8.47^{* * *}$ & $6.85^{* *}$ \\
\hline & $(0.09)$ & $(2.79)$ & $(3.02)$ \\
\hline Observations & 192 & 160 & 192 \\
\hline R-squared & 0.13 & 0.26 & 0.25 \\
\hline \multicolumn{4}{|l|}{ PANEL B } \\
\hline \multirow[t]{2}{*}{ Less Income } & -0.01 & 5.21 & 4.97 \\
\hline & $(0.10)$ & $(4.02)$ & $(3.70)$ \\
\hline \multirow[t]{2}{*}{ More Income } & -0.067 & $14.63^{* * *}$ & $11.53^{* *}$ \\
\hline & $(0.12)$ & $(5.07)$ & $(4.40)$ \\
\hline Observations & 201 & 166 & 201 \\
\hline R-squared & 0.13 & 0.20 & 0.17 \\
\hline \multicolumn{4}{|l|}{ PANEL C } \\
\hline \multirow[t]{2}{*}{ Education } & \multicolumn{2}{|c|}{ No Formal } & $7.68^{*}$ \\
\hline & $(0.09)$ & $(5.06)$ & $(4.21)$ \\
\hline \multirow[t]{2}{*}{ Formal Education } & -0.12 & 12.68 ** * & $9.18^{* *}$ \\
\hline & $(0.11)$ & $(4.11)$ & $(4.52)$ \\
\hline Observations & 201 & 166 & 201 \\
\hline R-squared & 0.13 & 0.19 & 0.16 \\
\hline
\end{tabular}

Note: Robust standard errors clustered on sessions in parentheses.

Extensive controls and enumerator FE included - see Appendix Table 2 for full results. ${ }^{* * *} \mathrm{p}<0.01,{ }^{* *} \mathrm{p}<0.05,{ }^{*} \mathrm{p}<0.1$ 
Table 6. Prediction Errors in the Cleric + Scripture Treatment Condition

\begin{tabular}{lcccc}
\hline & Obs & Mean & SD & p-value \\
\hline CLERIC+SCRIPTURE & & & & \\
\hline Average Contribution & 92 & 22.38 & 23.16 & 0.00 \\
Predicted Contribution & 85 & 12.43 & 11.29 & 0.00 \\
Prediction Error & 85 & 9.74 & 23.22 & 0.00 \\
Low Contributors & 35 & 17.68 & 18.39 & 0.00 \\
High Contributors & 50 & 4.18 & 24.77 & 0.24 \\
Low Contributors: & & & & \\
$\quad$ Less Income & 15 & 22.19 & 19.75 & 0.00 \\
$\quad$ More Income & 20 & 14.29 & 17.02 & 0.00 \\
No Formal Education & 26 & 16.48 & 17.44 & 0.00 \\
$\quad$ Formal Education & 9 & 21.13 & 7.21 & 0.02 \\
High Contributors: & & & & \\
Less Income & 25 & -1.88 & 16.30 & 0.57 \\
$\quad$ More Income & 25 & 10.24 & 30.17 & 0.10 \\
No Formal Education & 26 & 7.69 & 30.42 & 0.21 \\
Formal Education & 24 & 0.38 & 16.49 & 0.91 \\
\hline
\end{tabular}




$\begin{array}{lllllllll}(5) & (6) & (7) & (8) & (9) & (10) & \text { (11) } & \text { (12) }\end{array}$

\begin{tabular}{llllllll} 
VARIABLES & Contribute & Contribute & Contribute & Contribute & Cond Amt & Cond Amt & Cond Amt Cond Amt Average Average Average Average \\
\hline
\end{tabular}

\begin{tabular}{|c|c|c|c|c|c|c|c|c|c|c|c|c|}
\hline Cleric & $\begin{array}{c}0.33^{* * *} \\
(0.07)\end{array}$ & $\begin{array}{c}0.41^{* * *} \\
(0.08)\end{array}$ & $\begin{array}{c}0.43^{* * *} \\
(0.10)\end{array}$ & $\begin{array}{c}0.32^{* * *} \\
(0.09)\end{array}$ & $\begin{array}{c}-10.50^{* * *} \\
(3.33)\end{array}$ & $\begin{array}{c}-9.88^{* *} \\
(3.76)\end{array}$ & $\begin{array}{l}-9.70^{*} \\
(5.60)\end{array}$ & $\begin{array}{l}-6.66 \\
(4.93)\end{array}$ & $\begin{array}{l}-0.05 \\
(2.64)\end{array}$ & $\begin{array}{c}2.43 \\
(2.52)\end{array}$ & $\begin{array}{c}1.73 \\
(3.88)\end{array}$ & $\begin{array}{c}3.32 \\
(3.63)\end{array}$ \\
\hline \multirow[t]{2}{*}{ More Income } & & & 0.02 & -0.03 & & & -3.30 & -3.39 & & & -3.21 & -3.09 \\
\hline & & & $(0.12)$ & $(0.07)$ & & & $(6.74)$ & $(3.00)$ & & & $(4.98)$ & $(2.66)$ \\
\hline \multirow[t]{2}{*}{ Treatment X More Income } & & & -0.08 & & & & 0.27 & & & & 0.28 & \\
\hline & & & $(0.13)$ & & & & $(6.67)$ & & & & $(4.88)$ & \\
\hline \multirow[t]{2}{*}{ Formal Education } & & & -0.04 & -0.12 & & & -5.46 & -0.76 & & & -4.53 & -2.78 \\
\hline & & & $(0.06)$ & $(0.09)$ & & & $(4.00)$ & $(6.57)$ & & & (3.55) & $(4.80)$ \\
\hline \multirow[t]{2}{*}{ Treatment X Formal Education } & & & & 0.15 & & & & -7.48 & & & & -3.43 \\
\hline & & & & $(0.12)$ & & & & $(7.75)$ & & & & $(5.37)$ \\
\hline \multirow[t]{2}{*}{ Pashtun Ethnicity } & & 0.02 & 0.01 & 0.01 & & -0.77 & -1.50 & 1.06 & & -3.54 & -4.02 & -3.86 \\
\hline & & $(0.20)$ & $(0.21)$ & $(0.21)$ & & $(4.63)$ & $(4.18)$ & $(5.27)$ & & $(6.80)$ & $(6.88)$ & $(6.70)$ \\
\hline \multirow[t]{2}{*}{ Does Not Feel Poor } & & $0.25^{* * *}$ & $0.24^{* * *}$ & $0.24^{* * *}$ & & 1.12 & 1.23 & 1.13 & & $8.26^{* * *}$ & $8.38^{* * *}$ & $8.38^{* * *}$ \\
\hline & & $(0.08)$ & $(0.08)$ & $(0.08)$ & & $(3.58)$ & $(3.52)$ & $(3.47)$ & & $(2.87)$ & $(2.84)$ & $(2.81)$ \\
\hline \multirow[t]{2}{*}{ Age } & & -0.00 & 0.00 & 0.00 & & -0.09 & -0.09 & -0.11 & & -0.07 & -0.03 & -0.04 \\
\hline & & $(0.00)$ & $(0.00)$ & $(0.00)$ & & $(0.10)$ & $(0.10)$ & $(0.11)$ & & $(0.11)$ & $(0.09)$ & $(0.09)$ \\
\hline \multirow[t]{2}{*}{ Language Count } & & $0.11^{*}$ & $0.10^{*}$ & $0.11^{*}$ & & -1.99 & -1.79 & -2.12 & & 1.21 & 0.87 & 0.73 \\
\hline & & $(0.06)$ & $(0.06)$ & $(0.06)$ & & $(2.11)$ & $(1.87)$ & $(2.07)$ & & (1.44) & (1.43) & (1.49) \\
\hline \multirow[t]{2}{*}{ Married } & & 0.01 & 0.02 & 0.02 & & 0.15 & 0.33 & -0.04 & & 0.79 & 0.86 & 0.79 \\
\hline & & $(0.06)$ & $(0.06)$ & $(0.07)$ & & $(3.52)$ & $(3.22)$ & (3.23) & & $(3.52)$ & $(3.28)$ & $(3.22)$ \\
\hline \multirow[t]{2}{*}{ Qur'anic Education } & & $0.55^{* * *}$ & -0.10 & -0.10 & & $19.45^{* * *}$ & 3.78 & 3.92 & & $34.23^{* * *}$ & 1.66 & 1.44 \\
\hline & & $(0.17)$ & $(0.18)$ & $(0.17)$ & & (6.93) & (3.33) & (3.53) & & $(6.29)$ & $(5.51)$ & $(5.95)$ \\
\hline \multirow[t]{2}{*}{ Session Ethnic Mix } & & -0.01 & -0.01 & -0.01 & & 0.12 & 0.13 & 0.11 & & -0.10 & -0.08 & -0.09 \\
\hline & & $(0.00)$ & $(0.00)$ & $(0.00)$ & & $(0.21)$ & $(0.21)$ & $(0.20)$ & & $(0.21)$ & $(0.21)$ & $(0.21)$ \\
\hline \multirow[t]{2}{*}{ Time Taken (minutes) } & & $0.08^{*}$ & 0.07 & 0.07 & & $-5.07^{*}$ & $-4.55^{*}$ & $-4.63^{*}$ & & -1.42 & -0.99 & -1.06 \\
\hline & & $(0.04)$ & $(0.04)$ & $(0.04)$ & & $(2.57)$ & $(2.35)$ & $(2.36)$ & & $(1.73)$ & $(1.65)$ & $(1.68)$ \\
\hline \multirow[t]{2}{*}{ Waiting Time } & & 0.01 & 0.01 & 0.01 & & $-0.51^{* *}$ & $-0.51^{* *}$ & $-0.46^{* *}$ & & -0.23 & -0.28 & -0.26 \\
\hline & & $(0.01)$ & $(0.01)$ & $(0.01)$ & & $(0.23)$ & $(0.23)$ & $(0.22)$ & & $(0.23)$ & $(0.23)$ & $(0.22)$ \\
\hline \multirow[t]{2}{*}{ Monthly Income } & & -0.00 & & & & -0.00 & & & & -0.00 & & \\
\hline & & $(0.00)$ & & & & $(0.00)$ & & & & $(0.00)$ & & \\
\hline \multirow[t]{2}{*}{ Years Educated } & & -0.01 & & & & -0.37 & & & & -0.44 & & \\
\hline & & $(0.01)$ & & & & $(0.45)$ & & & & $(0.38)$ & & \\
\hline \multirow[t]{2}{*}{ Lincom Treatment + Interaction } & & & $0.35^{* * *}$ & $0.47^{* * *}$ & & & $-9.43^{* *}$ & $-14.14^{* *}$ & & & 2.01 & -0.11 \\
\hline & & & $(0.10)$ & $(0.11)$ & & & $(4.23)$ & $(5.27)$ & & & (3.28) & (3.84) \\
\hline
\end{tabular}




\begin{tabular}{|c|c|c|c|c|c|c|c|c|c|c|c|c|}
\hline Constant & $\begin{array}{c}0.50^{* * *} \\
(0.06)\end{array}$ & $\begin{array}{c}0.38 \\
(0.37)\end{array}$ & $\begin{array}{c}0.41 \\
(0.38)\end{array}$ & $\begin{array}{c}0.38 \\
(0.38)\end{array}$ & $\begin{array}{c}26.63^{* * *} \\
(3.03)\end{array}$ & $\begin{array}{c}61.41^{* *} \\
(27.78)\end{array}$ & $\begin{array}{c}60.09^{* *} \\
(26.10)\end{array}$ & $\begin{array}{c}61.18^{* *} \\
(26.05)\end{array}$ & $\begin{array}{c}13.45^{* * *} \\
(2.34)\end{array}$ & $\begin{array}{c}35.07 \\
(23.18)\end{array}$ & $\begin{array}{c}33.38 \\
(21.14)\end{array}$ & $\begin{array}{c}34.09 \\
(21.39)\end{array}$ \\
\hline Enumerator FE & No & Yes & Yes & Yes & No & Yes & Yes & Yes & No & Yes & Yes & Yes \\
\hline Observations & 213 & 202 & 210 & 210 & 144 & 137 & 142 & 142 & 213 & 202 & 210 & 210 \\
\hline R-squared & 0.12 & 0.26 & 0.24 & 0.24 & 0.10 & 0.26 & 0.27 & 0.28 & 0.00 & 0.14 & 0.13 & 0.13 \\
\hline
\end{tabular}

Robust standard errors clustered on sessions in parentheses. ${ }^{* *}{ }^{*} \mathrm{p}<0.01,{ }^{*}{ }^{*} \mathrm{p}<0.05,{ }^{*} \mathrm{p}<0.1$ 


\begin{tabular}{|c|c|c|c|c|c|c|c|c|c|c|c|c|}
\hline VARIABLES & $\begin{array}{c}(1) \\
\text { Contribute }\end{array}$ & $\begin{array}{c}(2) \\
\text { Contribute }\end{array}$ & $\begin{array}{c}(3) \\
\text { Contribute }\end{array}$ & $\begin{array}{c}(4) \\
\text { Contribute }\end{array}$ & $\begin{array}{c}(5) \\
\text { Cond Amt }\end{array}$ & $\begin{array}{c}(6) \\
\text { Cond Amt }\end{array}$ & $\begin{array}{c}\text { (7) } \\
\text { Cond Amt }\end{array}$ & $\begin{array}{c}\text { (8) } \\
\text { Cond Amt }\end{array}$ & $\begin{array}{c}(9) \\
\text { Average }\end{array}$ & $\begin{array}{c}(10) \\
\text { Average }\end{array}$ & $\begin{array}{c}(11) \\
\text { Average }\end{array}$ & $\begin{array}{c}\text { (12) } \\
\text { Average }\end{array}$ \\
\hline Cleric + Scripture & $\begin{array}{l}-0.02 \\
(0.07)\end{array}$ & $\begin{array}{l}-0.07 \\
(0.09)\end{array}$ & $\begin{array}{l}-0.01 \\
(0.10)\end{array}$ & $\begin{array}{c}0.01 \\
(0.09)\end{array}$ & $\begin{array}{c}11.32^{* * *} \\
(2.59)\end{array}$ & $\begin{array}{c}8.47 * * * \\
(2.79)\end{array}$ & $\begin{array}{c}5.21 \\
(4.02)\end{array}$ & $\begin{array}{c}6.92 \\
(5.06)\end{array}$ & $\begin{array}{c}8.99 * * * \\
(2.81)\end{array}$ & $\begin{array}{c}6.85^{* *} \\
(3.02)\end{array}$ & $\begin{array}{c}4.97 \\
(3.70)\end{array}$ & $\begin{array}{l}7.68^{*} \\
(4.21)\end{array}$ \\
\hline More Income & & & $\begin{array}{l}-0.03 \\
(0.09)\end{array}$ & $\begin{array}{l}-0.06 \\
(0.07)\end{array}$ & & & $\begin{array}{l}-0.43 \\
(2.94)\end{array}$ & $\begin{array}{c}4.19 \\
(3.09)\end{array}$ & & & $\begin{array}{l}-1.60 \\
(2.32)\end{array}$ & $\begin{array}{c}1.43 \\
(2.20)\end{array}$ \\
\hline Treatment X More Income & & & $\begin{array}{l}-0.05 \\
(0.13)\end{array}$ & & & & $\begin{array}{c}9.42 \\
(7.18)\end{array}$ & & & & $\begin{array}{c}6.56 \\
(5.44)\end{array}$ & \\
\hline Formal Education & & & $\begin{array}{c}0.03 \\
(0.05)\end{array}$ & $\begin{array}{c}0.09 \\
(0.07)\end{array}$ & & & $\begin{array}{l}-1.03 \\
(3.94)\end{array}$ & $\begin{array}{l}-3.95 \\
(4.87)\end{array}$ & & & $\begin{array}{l}-0.88 \\
(3.64)\end{array}$ & $\begin{array}{l}-1.83 \\
(4.55)\end{array}$ \\
\hline Treatment X Formal Education & & & & $\begin{array}{l}-0.13 \\
(0.09)\end{array}$ & & & & $\begin{array}{c}5.76 \\
(7.81)\end{array}$ & & & & $\begin{array}{c}1.50 \\
(6.44)\end{array}$ \\
\hline Pashtun Ethnicity & & $\begin{array}{c}0.08 \\
(0.14)\end{array}$ & $\begin{array}{c}0.07 \\
(0.14)\end{array}$ & $\begin{array}{c}0.07 \\
(0.14)\end{array}$ & & $\begin{array}{c}14.78^{* * *} \\
(4.96)\end{array}$ & $\begin{array}{c}10.83^{*} \\
(5.97)\end{array}$ & $\begin{array}{c}12.62^{* *} \\
(5.89)\end{array}$ & & $\begin{array}{c}12.41^{* * *} \\
(4.05)\end{array}$ & $\begin{array}{c}10.21 \text { * * } \\
(4.49)\end{array}$ & $\begin{array}{c}10.63^{* *} \\
(4.42)\end{array}$ \\
\hline Does Not Feel Poor & & $\begin{array}{c}0.05 \\
(0.07)\end{array}$ & $\begin{array}{c}0.07 \\
(0.07)\end{array}$ & $\begin{array}{c}0.06 \\
(0.07)\end{array}$ & & $\begin{array}{l}-0.07 \\
(4.46)\end{array}$ & $\begin{array}{c}3.62 \\
(3.82)\end{array}$ & $\begin{array}{c}3.35 \\
(4.07)\end{array}$ & & $\begin{array}{c}1.48 \\
(3.98)\end{array}$ & $\begin{array}{c}4.72 \\
(3.46)\end{array}$ & $\begin{array}{c}4.62 \\
(3.55)\end{array}$ \\
\hline Age & & $\begin{array}{c}0.00 \\
(0.00)\end{array}$ & $\begin{array}{c}0.00 \\
(0.00)\end{array}$ & $\begin{array}{c}0.00 \\
(0.00)\end{array}$ & & $\begin{array}{c}0.07 \\
(0.09)\end{array}$ & $\begin{array}{c}0.05 \\
(0.11)\end{array}$ & $\begin{array}{c}0.04 \\
(0.11)\end{array}$ & & $\begin{array}{c}0.10 \\
(0.09)\end{array}$ & $\begin{array}{c}0.11 \\
(0.09)\end{array}$ & $\begin{array}{c}0.11 \\
(0.09)\end{array}$ \\
\hline Language Count & & $\begin{array}{c}0.09 \\
(0.05)\end{array}$ & $\begin{array}{c}0.06 \\
(0.05)\end{array}$ & $\begin{array}{c}0.07 \\
(0.05)\end{array}$ & & $\begin{array}{l}-2.06 \\
(1.64)\end{array}$ & $\begin{array}{l}-2.84 \\
(2.11)\end{array}$ & $\begin{array}{l}-3.25 \\
(2.18)\end{array}$ & & $\begin{array}{l}-0.52 \\
(1.47)\end{array}$ & $\begin{array}{l}-1.75 \\
(2.10)\end{array}$ & $\begin{array}{l}-1.96 \\
(2.11)\end{array}$ \\
\hline Married & & $\begin{array}{l}-0.04 \\
(0.05)\end{array}$ & $\begin{array}{l}-0.02 \\
(0.06)\end{array}$ & $\begin{array}{l}-0.01 \\
(0.06)\end{array}$ & & $\begin{array}{l}-2.78 \\
(3.30)\end{array}$ & $\begin{array}{l}-3.00 \\
(3.37)\end{array}$ & $\begin{array}{l}-3.56 \\
(3.38)\end{array}$ & & $\begin{array}{l}-3.21 \\
(3.18)\end{array}$ & $\begin{array}{l}-2.97 \\
(3.20)\end{array}$ & $\begin{array}{l}-3.22 \\
(3.19)\end{array}$ \\
\hline Qur'anic Education & & $\begin{array}{l}0.12^{*} \\
(0.07)\end{array}$ & $\begin{array}{l}-0.10 \\
(0.12)\end{array}$ & $\begin{array}{l}-0.09 \\
(0.11)\end{array}$ & & $\begin{array}{c}58.07 \\
(51.25)\end{array}$ & $\begin{array}{c}16.02 \\
(15.84)\end{array}$ & $\begin{array}{c}15.60 \\
(16.33)\end{array}$ & & $\begin{array}{c}60.37 \\
(50.60)\end{array}$ & $\begin{array}{c}10.81 \\
(13.30)\end{array}$ & $\begin{array}{c}10.25 \\
(13.39)\end{array}$ \\
\hline Session Ethnic Mix & & $\begin{array}{c}0.00 \\
(0.00)\end{array}$ & $\begin{array}{c}0.00 \\
(0.00)\end{array}$ & $\begin{array}{c}0.00 \\
(0.00)\end{array}$ & & $\begin{array}{c}0.13 \\
(0.12)\end{array}$ & $\begin{array}{c}0.09 \\
(0.12)\end{array}$ & $\begin{array}{c}0.10 \\
(0.13)\end{array}$ & & $\begin{array}{c}0.19 \\
(0.14)\end{array}$ & $\begin{array}{c}0.18 \\
(0.14)\end{array}$ & $\begin{array}{c}0.19 \\
(0.14)\end{array}$ \\
\hline Time Taken (minutes) & & $\begin{array}{l}0.07 * \\
(0.03)\end{array}$ & $\begin{array}{l}0.06^{*} \\
(0.03)\end{array}$ & $\begin{array}{c}0.06 \\
(0.03)\end{array}$ & & $\begin{array}{l}-0.09 \\
(2.31)\end{array}$ & $\begin{array}{l}-0.29 \\
(2.70)\end{array}$ & $\begin{array}{c}0.13 \\
(2.59)\end{array}$ & & $\begin{array}{c}0.96 \\
(1.92)\end{array}$ & $\begin{array}{c}0.87 \\
(2.17)\end{array}$ & $\begin{array}{c}0.93 \\
(2.08)\end{array}$ \\
\hline Waiting Time & & $\begin{array}{c}0.01 \\
(0.00)\end{array}$ & $\begin{array}{c}0.00 \\
(0.00)\end{array}$ & $\begin{array}{c}0.00 \\
(0.00)\end{array}$ & & $\begin{array}{l}-0.35^{*} \\
(0.19)\end{array}$ & $\begin{array}{l}-0.15 \\
(0.26)\end{array}$ & $\begin{array}{l}-0.20 \\
(0.23)\end{array}$ & & $\begin{array}{l}-0.23 \\
(0.18)\end{array}$ & $\begin{array}{l}-0.12 \\
(0.22)\end{array}$ & $\begin{array}{l}-0.14 \\
(0.21)\end{array}$ \\
\hline Monthly Income & & $\begin{array}{c}0.00 \\
(0.00)\end{array}$ & & & & $\begin{array}{c}0.00 \\
(0.00)\end{array}$ & & & & $\begin{array}{c}0.00 \\
(0.00)\end{array}$ & & \\
\hline Years Educated & & $\begin{array}{c}0.00 \\
(0.00)\end{array}$ & & & & $\begin{array}{c}0.18 \\
(0.38)\end{array}$ & & & & $\begin{array}{c}0.14 \\
(0.38)\end{array}$ & & \\
\hline Lincom Treatment + Interaction & & & $\begin{array}{l}-0.067 \\
(0.12)\end{array}$ & $\begin{array}{l}-0.12 \\
(0.11)\end{array}$ & & & $\begin{array}{c}14.63^{* * *} \\
(5.07)\end{array}$ & $\begin{array}{c}12.68^{* * *} \\
(4.11)\end{array}$ & & & $\begin{array}{c}11.53^{* *} \\
(4.40)\end{array}$ & $\begin{array}{c}9.18^{* *} \\
(4.52)\end{array}$ \\
\hline
\end{tabular}




\begin{tabular}{lcccccccccccc} 
Constant & $0.83^{* * *}$ & 0.30 & 0.34 & 0.32 & $16.13^{* * *}$ & 11.79 & 21.05 & 20.19 & $13.39^{* * *}$ & -2.22 & 6.66 & 5.32 \\
& $(0.04)$ & $(0.29)$ & $(0.29)$ & $(0.30)$ & $(1.39)$ & $(17.15)$ & $(18.94)$ & $(18.63)$ & $(1.21)$ & $(16.07)$ & $(16.81)$ & $(17.35)$ \\
Enumerator FE & No & Yes & Yes & Yes & No & Yes & Yes & Yes & No & Yes & Yes & Yes \\
Observations & 204 & 192 & 201 & 201 & 168 & 160 & 166 & 166 & 204 & 192 & 201 & 201 \\
R-squared & 0.00 & 0.13 & 0.13 & 0.13 & 0.09 & 0.26 & 0.20 & 0.19 & 0.06 & 0.25 & 0.17 & 0.16 \\
\hline
\end{tabular}

Robust standard errors clustered on sessions in parentheses. ${ }^{* *}{ }^{*} \mathrm{p}<0.01,{ }^{* *} \mathrm{p}<0.05,{ }^{*} \mathrm{p}<0.1$ 